\title{
İngilizce Hazırlık Programına Devam Eden Üniversite Öğrencilerinin İngilizce Özyeterlik İnançlarının İncelenmesi
}

\author{
Öğr. Gör. Aydan Seher İlbeği ${ }^{1 *}$ \\ Dr. Öğr. Üyesi Mine Çeliköz ${ }^{2}$
}

Gelis tarihi: 19.03 .2020

Kabul tarihi: 20.04.2020

\section{Atıf bilgisi: \\ IBAD Sosyal Bilimler Dergisi \\ Sayı: $8 \quad$ Sayfa: $14-34$ \\ Yıl: 2020 Dönem: Güz}

This article was checked by Turnitin. Similarity Index 17\%

Bu makalede araştırma ve yayın etiğine uyulmuştur.

1 İstanbul Sabahattin Zaim Üniversitesi, Turkey, aydanseher@gmail.com. ORCID ID 0000-0002-5872-5966

2 Yıldız Teknik Üniversitesi, Turkey, mcelikoz25@gmail.com

ORCID ID 000000031582 331X

* Sorumlu yazar
ÖZ

$\mathrm{Bu}$ araştırmanın amacı İngilizce hazırlık programına devam eden üniversite öğrencilerinin İngilizce özyeterlik inanç düzeylerini ve bazı kişisel özelliklerin İngilizce özyeterlik inancında etkili olup olmadığını belirlemektir. Araştırma, nicel araştırma desenlerinden betimsel tarama desenine göre tasarlanmıştır. Araştırmanın çalışma grubunu İstanbul'da bir özel üniversitenin ve bir devlet üniversitesinin hazırlık bölümünde öğrenim gören 410 öğrenci oluşturmaktadır. Araştırmanın verileri Hanc1-Yanar ve Bümen (2012) tarafindan geliştirilen "İngilizce ile İlgili Özyeterlik İnancı Ölçeği” kullanılarak toplanmıştır. Veri analizinde öğrencilerin kişisel özellikleri ve İngilizce özyeterlik inancını belirlemede betimsel istatistiklerden, bazı kişisel özelliklerine göre özyeterlik düzeyleri arasında fark olup olmadığının belirlenmesinde ise t-testi ve tek yönlü varyans analizinden yararlanılmıştır. Araştırma sonucunda öğrencilerin İngilizce özyeterlik inancının orta düzeyde olduğu saptanmıştır. Öğrencilerin İngilizce özyeterlik inanç düzeyleri en yüksek okuma becerisinde ortaya çıkarken bunu sırasıyla dinleme, konuşma ve yazma becerileri takip etmiştir. Kişisel özellikler açısından öğrencilerin cinsiyeti, herhangi bir işte çalışma durumu, kaldığı ortam ve aylık harcaması İngilizce özyeterlik inancı üzerinde etkili bulunmazken; okul türü, akademik başarı, dil seviyesi ve yaşadığı yer değişkenlerinin İngilizce özyeterlik inancında etkili olduğ tespit edilmiştir.

Anahtar Kelimeler: İngilizce Özyeterlik, Özyeterlik İnancı, İngilizce Hazırlık Eğitimi, Üniversite Öğrencileri 
Investigation of English Self-Efficacy Beliefs of the Students Who Are Studying English at Preparatory Schools

\author{
Lec. Aydan Seher İlbeği ${ }^{1 *}$ \\ Assist. Prof. Dr. Mine Çeliköz $z^{2}$
}

First received: 19.04 .2020

Accepted: 20.04 .2020

Citation:

IBAD Journal of Social Sciences

Issue: $8 \quad$ Pages: 14-34

Year: $2020 \quad$ Session: Fall

This article was checked by Turnitin. Similarity Index 17\%

1 İstanbul Sabahattin Zaim University, Turkey, aydanseher@gmail.com. ORCID ID 0000-0002-5872-5966

2 Ylldı Teknik University, Turkey, mcelikoz25@gmail.com ORCID ID 0000-0003-1582-331X

* Corresponding Author

Keywords: English Self Efficacy, Self-Efficacy Belief, English Preparatory Class, University Students. 


\section{GíRIŞ}

Tarih öncesi dönemlerden günümüze değin sayılamayacak kadar fazla ve aynı zamanda büyük gelişmeler yaşanmıştır. Tüm bunlar dünyanın fiziksel ve kimyasal yapısını değiştirirken aslında bunların müsebbibi olan insanoğlunun kendisi de şüphesiz değişmiştir. Yemekleri, giyimi, kullandıkları eşyalarıyla birlikte bakıș açıları, değerleri ve inançları da bu değişimden nasibini almıștır. Bununla birlikte değişmeyen özellikler de mevcuttur. Doğuştan getirilen ve genetik kodlarla aktarılan; sevgi, saygı, merhamet, yardımsever olma gibi değerlerin yanında, hayatta kalabilme ve doğayla baş edebilme becerilerinin de değişmeyen özellikler olduğu söylenebilir. İnsanların karnını doyurma, kendini güvende hissetme, tehlikelerden korunma gibi arzuları geçmişte olduğu gibi bugün de geçerliliğini korumakta ve bireyler geçmişte olduğu gibi günümüzde de bir arada yaşama eğilimi göstermektedir. Ortak değerlerin birikimi, ihtiyaçların çeşitlenmesi, paylaşma ve dayanışmanın öneminin artması gibi nedenler ise toplumsal yaşamı vazgeçilmez kılmakta, birey ve grupların etkileşimini artırmaktadır.

Toplumsal yaşamda bireylerin dayanışma içinde olması, duygu ve düşüncelerini paylaşabilmesi için birbirleriyle iletişim kurması gerekmektedir. Bunun için her birey, içinde bulunduğu toplumun dilini kullanır (İşeri, 1996) ve bu sayede yaşadığı toplumla ile bir bağ oluşturur (Canbulat ve İşgören, 2005). $\mathrm{Ne}$ var ki bilimsel ve teknolojik gelişmelerle birlikte, toplumların da birbirleriyle etkileşimi söz konusu olmakta, hatta bu etkileşim gün geçtikçe artmaktadır. Bu durumda ana dilde iletişim yetersiz kalmakta ve ana dili dışında başka diller ile iletişim kurulması gerekmektedir. Dolayısıyla dünyadaki gelişmeleri takip edebilmek ve bu sürece katkı getirebilmek ancak diğer toplumların dilini öğrenmekle mümkün görünmektedir.

Aydemir'e (2007) göre, çağı yakalamanın, bilimsel dünyada ve değişen dünya koşullarında var olmanın en önemli aracı dildir. Gelişmelerden haberdar olabilmek, bilimsel araştırmaları kaynak dilde takip edebilmek, iyi araştırma yapabilmek, elde edilen bilgileri paylaşabilmek ve uluslararası düzeyde rahat iletişim kurabilmek ancak ikinci bir dilin öğrenilmesiyle mümkündür (Canbulat ve İşgören, 2005). Türkiye de gelişmekte olan bir ülke olarak bu doğrultuda diğer ülkeler ile yoğun siyasi, kültürel ve ekonomik etkileşimlerde bulunmaktadır. Öte yandan yabancı ülkelerin Türkiye'ye karşı ilgisi de artmaktadır. Ülkeler arası bu etkileşimi sağlayacak olan dil, şüphesiz ki İngilizcedir (Arslan ve Akbarov, 2010). İngilizceyi öncelikli dil haline getiren temel nedenler ise dünya ticaretindeki etkililiği, bilimsel dil olmadaki yaygınlığı ile birinci dili İngilizce olan ülkelerin dünya üzerindeki siyasi ve askeri gücüdür (Canbulat ve İşgören, 2005). 2013 yılında British Council ve Türkiye Ekonomi Politikaları Araştırma Vakfi (TEPAV), ülke çapında İngilizce öğretimine ilişkin bir ihtiyaç analizi çalışması yapmış ve neden İngilizce öğrenilmesi gerektiğini şöyle sıralamıştır (TEPAV, 2013, s. 30-36):

1. İngilizce dünyadaki en yaygın dillerden birisidir.

2. Dünyadaki ana iletişim dili olarak İngilizceyi kullanmanın hem makroekonomik hem de bireysel düzeyde olumlu etkileri olabilir.

3. İngilizce iletişim kurabiliyor olmak bir ülkenin uzun dönemli ekonomik büyüme potansiyelini, o ülkenin inovasyon kapasitesini arttırarak, olumlu yönde etkileyebilir.

4. Bir çok ülkenin kendi başına inşa edemediği altyapıyı oluşturmak için önemli olan bölgesel entegrasyon, fiziksel kaynakların ve insan kaynaklarının yakınlığı ve kullanılabilirliği, karşılıklı bağımlılık ve dayanışma, bölgesel ticaret bloklarının sayısında artış ve daha da önemlisi ortak bir dil gibi faktörler tarafından teşvik edilmektedir.

5. İngilizce, uluslararası iletişimde kullanılan temel dil olması itibariyle turizm sektörü için önemli bir beceridir .

6. İşletmelerin küresel olarak gittikçe daha fazla iletişim halinde olmaları nedeniyle, yetenekli çalışanlara yönelik açık kadrolar İngilizce dilinde yüksek düzeyde iletişim becerileri gerektirmektedir.

Buna göre yabancı dil olarak İngilizce bilmek, hem bireysel hem de toplumsal açıdan büyük avantaj ve yararları beraberinde getirmektedir. Bunun bilincinde olan Türk Milli Eğitim sisteminin de, özellikle son yıllarda İngilizce öğrenmeyi çok fazla önemsediği söylenebilir. Nitekim ilkokul ikinci sınıftan itibaren 
ögretim programlarında İngilizce dersine yer vermekte ve programlar yeniden düzenlenmektedir. Ancak ne yazık ki ilköğretimden üniversite eğitimine kadar yüzlerce saat İngilizce eğitimi yapılmasına rağmen yabancı dildeki başarı istenilenin çok daha altındadır (Arslan ve Akbarov, 2010).

Öğrencilerin bir dili öğrenmesini doğrudan ya da dolaylı olarak etkileyen birçok faktör vardır. $\mathrm{Bu}$ sebeple yabancı dil öğrenme sürecinde bireysel farklılıkların göz önünde bulundurularak öğretim programı hazırlanması; uygun etkinliklerin, materyallerin, öğretim yöntem/tekniklerinin geliştirilmesi gerekmektedir. Ayrıca öğrencilere olumlu bir öğrenme ortamı oluşturulması ve duyuşsal özelliklerinin de geliştirilmesi önem arz etmektedir (Oğuz ve Akbaş Baysal, 2015). Çünkü ilgi, tutum, motivasyon, kaygı, özyeterlik gibi davranışları içeren duyuşsal özellikler, öğrenmeyi önemli ölçüde etkilemektedir (Gömleksiz, 2003).

Öğrencinin duyuşsal özelliklerinin olumlu yönde geliştirilmesi sınıf ortamını da olumlu yönde etkilemektedir. Öğrencilerin derslerde aktif olmaları, birbirlerini destekleyici etkileşimlerde bulunmaları, olumlu bir sosyokültürel ortamın varlığı duyuşsal davranışlarla yakından ilgilidir ve başarıda önemli katkı sağlamaktadır. Öğrencilerin işbirliği yapmasına imkan veren duyuşsal davranışlar, onları öğrenme sürecinde de aktif tutabilmektedir (Gömleksiz, 2003). Yabancı dil öğreniminde de, öğretmenlerin daha aktif olduğu geleneksel sınıf ortamları değil, öğrencilerin aktif olduğu ve hedef dilde karșılıklı etkileşimde bulunmalarına imkan tanıyan ortamların daha etkili ve başarılı olacağı söylenebilir.

Her öğretim programında olduğu gibi yabancı dil öğretim programlarının da başarılı oluşunda güdülenme, tutum ve özyeterlik gibi duyuşsal özellikler önem arz etmektedir (Hanc1-Yanar ve Bümen, 2012). Öğrenmenin, öğrencinin gerçekten öğrenmek istemesi ile gerçekleştiği gerçeği göz önünde bulundurulduğunda öğrenciyi harekete geçirebilecek etkinliklerin öğretmen tarafindan bilinmesi ve bunların öğrenme ortamında bilinçli bir biçimde uygulaması önemlidir (Acat ve Demiral, 2002). Şüphesiz ki özyeterlik inancı, öğrenme istek ve motivasyonunu etkileyen faktörlerin başında gelmektedir. Özyeterlik kavramı, Bandura'nın Sosyal Bilişsel Kuramı ile ön plana çıkmıştır. Özyeterlik, bireyin bir performansı gerçekleştirebilmek için kendi kapasitesine ilişkin yargısı olarak tanımlanabilir (Bandura, 1994; Bandura, 1999). Woolfolk'a (2016, s. 444) göre özyeterlik, "bireyin herhangi bir alanda kendi yetenek ve etkililiği ile ilgili düşünceleridir". Diğer bir deyişle, bireyin gelecekte karşılaşabileceği sınava girme, yarışmaya katılma, bir topluluk önünde konuşma vb. gibi güç durumların üstesinden gelmede ne derece başarılı olabileceğine ilişkin kendisi ile ilgili inancını (Senemoğlu, 2018) ifade etmektedir. Bireyin hayattaki seçimlerinin, koyduğu hedeflerin, ne kadar çabalayacağının, zorluklara ne kadar tahammül edeceğinin belirleyicisidir (Bandura ve Zimmerman, 1992; Bandura, 1999; Senemoğlu, 2018). Bu durum öğrenme sürecindeki motivasyonun devamında ve başarıya ulaşmada özyeterliğin dikkate alınması gereken bir önemli bir değişken olduğunu göstermektedir.

Bandura'ya (1977, s. 218) göre, "yüksek özyeterlik inancı yüksek akademik başarıyı da beraberinde getirmektedir". Bireyler yüksek özyeterlik inancına sahipse kendine daha yüksek hedefler koymakta ve başarısızlıktan daha az korkmaktadır. Kendisine olan inancı arttıkça kendisi için koyduğu hedeflerin zorluğu da artmaktadır (Pajares, 2002). Bireyin özyeterlik inancı arttıkça herhangi bir işi denemekten korkmamakta (Açıkgöz, 2016), gösterdiği çaba ve kararlılığı da artmaktadır (Bandura, 1999; Bandura, 2000). Yüksek özyeterlik inancına sahip olan bireyler zorluklar karşısında direnç gösterebilirken, düşük olanlar daha az çabalamakta ya da çabalamayı bırakıp vazgeçme eğilimi göstermektedir (Bandura, 1982; Woolfolk, 2016).

İngilizce öğretiminde okuma, yazma, dinleme ve konuşma olmak üzere dört temel beceri bulunmaktadır. Büyükduman'a (2006) göre, öğrencilerin bu becerilerde kendini ne kadar yetkin olarak algıladığı, bu konudaki öz yeterlik inancına yönelik bilgi vermektedir. Öğrenciler yeni bir dil öğrenirken yeteneklerini sorgulamakta ve yetkinliklerine ilişkin kanaat oluşturmaktadır. Bu kanaat onların motivasyonlarını ve başarılarını doğrudan etkilemektedir. Eğer öğrenme sürecine düşük bir özyeterlik inancı ile başlarlarsa dil ögrenmedeki başarılarının da olumsuz yönde etkilenmesi muhtemeldir (Hancı- Yanar ve Bümen, 2012). Özellikle yüzlerce saat eğitim yapılan İngilizce hazırlık sınıflarında öğrencilerin özyeterlik inancının düşük olması, onların performans ve başarılarını olumsuz yönde etkileyen nedenlerin başında gelmektedir. Hem yurtiçinde hem de yurtdışında ilgili alanyazın incelendiğinde İngilizce özyeterlik ile akademik başarı arasındaki ilişkiyi inceleyen pek çok çalışmanın olduğu görülmektedir (White ve Bowers, 2008; Raoofi, Tan ve Chan, 2012; Siritararatn, 2013; Gömleksiz ve Kılınç, 2014; Güç, 2019). 
$\mathrm{Bu}$ çalışmaların da işaret ettiği gibi özyeterlik ve başarı birbirinden etkilenen ve birbirini besleyen iki önemli kaynak olarak görülmektedir. Öğrencinin başarısı arttıkça özyeterlik inancı da artmaktadır. Başarılı deneyimler özyeterlik inancı oluşturmada olumlu katkı sağlarken, başarısız deneyimler ise özyeterlik inancının düşmesine neden olmaktadır (Büyükduman, 2006).

Türkiye'de İngilizce'ye karşı ilgi her geçen gün artmaktadır. Bireylerin bilgi çağını yakalaması ve evrensel gelişmeleri takip edebilmesi için küresel bir dil olan İngilizceyi öğrenmesi bir zorunluluk haline gelmiştir. Özellikle üniversite öğrencileri lisans eğitimini tamamladıktan sonra gerek iş hayatı gerekse günlük hayatlarında başarılı birer yetişkin olabilmek için İngilizce bilmeye ihtiyaç duymaktadır. Ancak ne yazık ki Türkiye'de İngilizce öğretiminin önemi kabul edilmesine rağmen bu alandaki başarı istenilen düzeyde değildir (Demirpolat, 2015). Başarı ve performansı etkileyen en önemli psikolojik faktörlerden biri olan özyeterlik inancının eksikliği, öğrencilerin dil öğrenim sürecindeki performansını da olumsuz etkileyerek başarısız olmalarına neden olabilmektedir. Öğrencilerin özyeterlik inançlarını ve bunun bir sonucu olarak da başarılarını arttıracak bir döngünün kurulması, yabancı dil öğretimi için elzem görünmektedir (Turanlı, 2007). Öğrencilerin İngilizce özyeterlik inancına dair elde edilecek bilgiler öğrencilerin İngilizce özyeterlik inancının geliştirilmesinde, öğretmenlerin özyeterlik inancını arttıracak öğrenme ortamları oluşturmasında, program tasarımcılarının materyal geliştirmesinde ve programların içeriğinin düzenlenmesinde dolayısıyla öğrencilerin İngilizcede daha başarılı olması ve gelecekte de başarılı birer yetişkin olması yolunda yardımcı olacaktır. Bu yüzden ilk etapta öğrencilerin İngilizce özyeterlik inançlarının ne düzeyde olduğunu belirleyen çalışmaların yapılması gerekmektedir. $\mathrm{Bu}$ doğrultuda bu çalışmada İngilizce hazırlık programında öğrenim gören üniversite öğrencilerinin İngilizce özyeterlik inançları ele alınmıştır. Çalışmanın, İngilizce eğitiminin yoğun bir programla yapıldığı hazırlık okullarında gerçekleştirilmesi ve İngilizce özyeterlik inancı üzerinde etkili olan faktörlerin ortaya çıkarılması nedeniyle önemli olduğu ve araştırmada elde edilen bulgularının ilgili sorunların çözümüne katkı getirebileceği düşünülmektedir.

\section{Araştırmanın Amacı}

$\mathrm{Bu}$ araştırmanın amacı İngilizce hazırlık programına devam eden üniversite öğrencilerinin İngilizce özyeterlik inanç düzeylerini ve bazı kişisel özelliklerin İngilizce özyeterlik inancında etkili olup olmadığını belirlemektir. Bu amaç doğrultusunda aşağıdaki sorulara cevap aranmıştır:

İngilizce hazırlık programına devam eden üniversite öğrencilerinin İngilizce özyeterlik inanç düzeyleri;

1. Okuma, yazma, dinleme ve konuşma becerileri yönünden ne düzeydedir?

2. Kişisel değişkenlere göre (cinsiyet, yaş, okul türü, akademik başarı, İngilizce dil seviyesi, yaşadığı yer, kaldığı yer, bir işte çalışma durumu ve aylık harcama durumu) farklılaşmaktadır mıdır?

\section{YÖNTEM}

\section{Araştırmanın Modeli}

Araştırma, nicel araştırma yöntemi doğrultusunda betimsel tarama desenine göre tasarlanmıştır. Tarama modeli, geçmişte ya da hala var olan bir durumu herhangi bir etkileme çabası göstermeden var olduğu hali ile tanımlamaya çalışan araştırma modelidir (Karasar, 2017). Bu araştırma ile İngilizce hazırlık programındaki öğrencilerin İngilizce özyeterlik inançları ve özyeterlik inançlarında bazı değiş̧kenlere göre farklılık olup olmadığı belirlenmeye çalışılmaktadır. Çalışmada öğrencilerin mevcut İngilizce özyeterlik inançları herhangi bir etkiye maruz bırakılmamış, olduğunu gibi betimlenmeye çalışılmıştır.

\section{Çalışma Grubu}

Araştırmanın çalışma evrenini 2019 bahar ve güz yarıyılında İstanbul'da bir özel ve bir de devlet üniversitesine kayıtlı İngilizce hazırlık programı öğrencileri oluşturmaktadır. Çalışma grubu ise, çalışma evreni içerisindeki farklı dil seviyelerinden küme örnekleme yöntemiyle gönüllülük ilkesine dayalı olarak seçilen toplam 410 öğrenciden oluşmaktadır. Küme örnekleme yöntemi, evrendeki tüm öğeleri içermemekle birlikte bu öğelerin benzer özelliklerine göre gruplandırılabilmesi sebebiyle kullanışlı bir yöntemdir (Morgan ve Morgan, 2008). Bu yöntemde, kümelerin benzer özellikleri sayıca fazla olması arzulanmakla birlikte en az bir özelliği benzer olduğunda da gruplar küme olarak belirlenebilir (Creswell ve Clark, 2016). Bu çalışmada hazırlık sınıflarında bulunan öğrenciler, farklı dil seviyelerine göre 
gruplandırılarak öğrenim gördüğü için her bir seviye bir küme olarak kabul edilmiştir. Öğrencilerin eğitim aldığ1 kurumlarda dil seviyeleri A1, A2, B1, B2, C1 ve C2 şeklinde belirlenmiştir. B2 seviyesini başarıyla tamamlayan öğrenciler genellikle hazırlık eğitimini tamamlamış olarak kabul edilmektedir. $\mathrm{Bu}$ yüzden küme örnekleme yöntemine A1, A2, B1 ve B2 seviyedeki öğrenciler dahil edilmiş, C düzeyinde öğrenci sayısı çok az olduğu için araştırma kapsamına alınmamıştır. Tablo 1'de araştırmada yer alan öğrencilere ilişkin kişisel bilgiler yer almaktadır.

Tablo 1. Öğrencilere iliş̧kin kişsisel bilgiler

\begin{tabular}{|c|c|c|c|}
\hline Değişken & Gruplar & $\mathbf{n}$ & $\%$ \\
\hline \multirow{2}{*}{ Cinsiyet } & Kadın & 229 & 55,9 \\
\hline & Erkek & 181 & 44,1 \\
\hline \multirow{2}{*}{ Yaş } & $18 v e$ altı & 147 & 35,9 \\
\hline & 19 ve üzeri & 263 & 64,1 \\
\hline \multirow{2}{*}{ Okul türü } & Devlet üni. & 202 & 49,3 \\
\hline & Vakıf üni. & 208 & 50,7 \\
\hline \multirow{4}{*}{ İngilizce Seviyesi } & A1 & 84 & 20,5 \\
\hline & $\mathrm{A} 2$ & 137 & 33,4 \\
\hline & B1 & 86 & 21,0 \\
\hline & B2 & 103 & 25,1 \\
\hline \multirow{2}{*}{ Akademik başarı } & Orta ve altı & 168 & 41 \\
\hline & İyi ve çok iyi & 242 & 59 \\
\hline \multirow{3}{*}{ Yaşadığı yer } & Büyükșehir & 349 & 85,1 \\
\hline & Diğer & 61 & 14,9 \\
\hline & Aile & 252 & 61,5 \\
\hline \multirow[t]{2}{*}{ Kalınan yer } & Yurt & 112 & 27,3 \\
\hline & Diğger & 46 & 11,2 \\
\hline \multirow{3}{*}{ Çalışma durumu } & Evet & 49 & 12 \\
\hline & Hayır & 261 & 88 \\
\hline & 500 ve alt 1 & 96 & 23,4 \\
\hline \multirow{4}{*}{ Aylık harcama durumu } & $501-750$ & 137 & 33,4 \\
\hline & $751-1000$ & 75 & 18,3 \\
\hline & $1001-1500$ & 53 & 12,9 \\
\hline & 1501ve üzeri & 49 & 12 \\
\hline Toplam & & 410 & \\
\hline
\end{tabular}

Tablo 1 incelendiğinde, çalışma grubunda yer alan öğrencilerin 229'unun kadın $(\% 55,9)$ 181'inin $(\% 44,1)$ erkek olduğu, yaşlarının 17 ile 26 arasında değiştiği görülmektedir. Öğrencilerin 208 'i $(\%$ 50,7) özel üniversitede, 202' si $(\% 49,1)$ devlet üniversitesinde eğitim görmektedir. İngilizce dil seviyesi açısından A1 düzeyinde olanlar çalışma grubunun \% 20,5'ini (84 kişi), A2 düzeyinde olanlar \%33,4'ünü (137 kişi), B1 düzeyinde olanlar \%21'ini (86 kişi) ve B2 düzeyinde olanlar \%25,1'ini (103 kişi) oluşturmaktadır. Öğrencilerin \%59'unun (242 kişi) akademik başarısı iyi ve çok iyi, \%41 inin (168 kişi) ise orta ve altındadır. Büyükşehirde yaşayan öğrenciler çalışma grubunun \%85,1'ini (349 kişi), şehir, köy veya kasabada yaşayanlar ise \%14,9'unu (61 kişi) oluşturmaktadır. Öğrencilerin \%61'i (252 kişi) ailesi ile yaşarken, \%27,3'ü (112 kişi) yurtta, \%11,2'si (46 kişi) de öğrenci evinde ya da akrabalarının yanında yaşamaktadır. Çalışan öğrenciler, çalışma grubunun \%12'sini (49 kişi), çalışmayanlar ise \%88'ini (261 kişi) oluşturmaktadır. Öğrencilerin \%23,4'ünün (96 kişi) aylık harcaması 500 tl ve altında, \%33,4'ünün (137 kişi) 501-750 tl arasında, \%18,3'ünün (75 kişi) 751-1000 tl arasında, \%12,9'unun (53 kişi) 10011500 tl arasında ve \%12'sinin (49 kişi) 1501 tl ve üzerindedir.

\section{Veri Toplama Aracı}

Araştırmada veri toplamak amacıyla Hanc1-Yanar ve Bümen (2012) tarafindan geliştirilen Ingilizce Özyeterlik İnancı Ölçeği ve kişisel bilgi formu kullanılmıştır. İngilizce Özyeterlik İnancı Ölçeği; okuma, yazma, dinleme ve konuşma olmak üzere 4 boyuttan oluşmaktadır. Okuma boyutunda 8 , yazma boyutunda 10, dinleme boyutunda 10 ve konuşma boyutunda 6 madde bulunan ölçekte toplamda 34 madde bulunmaktadır. Beşli Likert tipinde geliştirilen ölçekte her bir maddenin puanlaması; "(1) hiç uymuyor", “(2) az uyuyor”, “(3) orta düzeyde uyuyor", “(4) oldukça uyuyor” ve "(5) tamamen uyuyor” 
şeklinde yapılmıştır. Ters puanlama maddesinin bulunmadığı ölçekte, alınabilecek yüksek puanlar yüksek özyeterlik inancını temsil etmektedir. Ölçeğin geçerlik ve güvenirliğine ilişkin Bümen ve Yanar tarafindan yapılan analizlerde Cronbach's Alpha güvenirlik katsayısı 0.97, boyutların toplam varyans1 açıklama oranı \%61,41 olarak hesaplanmıştır. Bu değer her ne kadar ölçeğin geçerli ve güvenirliği konusunda ikna edici olsa da örneklem farklılığından dolayı yeniden geçerlik ve güvenirlik çalışmaları yapılmıştır. Bu doğrultuda167 hazırlık sınıfı öğrencisi üzerinde yapılan pilot uygulama verileri analize tabi tutulmuştur. İlk etapta Cronbach Alpha ve testi yarılama yöntemi kullanılarak ölçekte yer alan maddelerin tutarlılığı incelenmiştir. Yapılan analizlerde ölçeğin tümü için testi yarılama yöntemiyle hesaplanan Spearman Brown güvenirliği 0.89, Cronbach Alpha güvenirliği 0.96 bulunmuştur. Geçerlik çalışması doğrultusunda yapılan analizlerde ise ölçekteki birinci faktörün toplam variyansa \%21,69 katkı getirdiği, ikinci faktörün \%19,48, üçüncü faktörün \%16,53, dördüncü faktörün de $\% 3,80$ katk1 getirerek açıklanan toplam variyansı \%61,49'a çıkardığı gözlenmiştir. Bu sonuca göre İngilizce Özyeterlik İnanc1 ölçeğinin bu araştırma için de geçerli bir ölçme aracı olduğu kabul edilmiştir.

\section{Verilerin Toplanması ve Analizi}

Araştırmanın verileri üniversitelerin İngilizce hazırlık eğitimi koordinatörlüklerinden gerekli resmi izinler alındıktan sonra ders saati içerisinde toplanmıştır. Ölçekler 10-15 dakikalık süre zarfında doldurulmuştur. Elde edilen veriler SPSS paket programı aracılığı ile analiz edilmiştir. Araştırmada öncelikle verilerin dağılımı ve homojenliği tespit edilmeye çalışılmıştır. Bu doğrultuda yapılan analizlerde arimetik ortama $(3,23)$, ortanca $(3,23)$, Skewness (çarpıklık: -0,33), Kurtosis (basıklık: -0,45), Kolmogorov-Smirnov $(\mathrm{p}=0,2)$ değerleri incelenerek dağılımın normal olduğu belirlenmiştir. Verilerin analizinde kişisel özellikleri ve İngilizce özyeterlik inancını belirlemede betimsel istatistiklerden frekans (f), yüzde (\%), aritmetik ortalama $(\overline{\mathrm{X}})$ ve standart sapmadan (ss); bazı kişisel özelliklerine göre özyeterlik düzeyleri arasında fark olup olmadığının belirlenmesinde de t-testi ve tek yönlü varyans analizinden (ANOVA) yararlanılmıştır (Can, 2014). Farkl111kların test edilmesinde 0.05 anlamlılık düzeyi kullanılmıştır.

\section{BULGULAR}

$\mathrm{Bu}$ bölümde İngilizce hazırlık programına devam eden üniversite öğrencilerinin İngilizce özyeterlik inanç düzeylerine ve bazı kişisel özelliklerin İngilizce özyeterlik inancında etkili olup olmadığına ilişkin bulgulara yer verilmiştir. Elde edilen bulgular araştırmanın alt amaçları doğrultusunda tablolarla birlikte sunulmuştur.

\section{1. İngilizce Hazırlık Programına Devam Eden Üniversite Öğrencilerinin İngilizce Özyeterlik İnanç Düzeyleri}

Araştırmanın birinci alt amacı doğrultusunda ilk olarak, İngilizce hazırlık programına devam eden üniversite öğrencilerinin İngilizce özyeterlik inanç düzeyleri genel olarak ve okuma, yazma, dinleme ve konuşma boyutları açısından belirlenmeye çalışılmıştır. Tablo 2'de İngilizce özyeterlik inanç düzeyleri ve alt boyutlara ilişkin bazı betimsel istatistikler verilmiştir.

Tablo 2. Ingilizce hazırlık programına devam eden öğrencilerinin İngilizce özyeterlik inanç düzeyleri

\begin{tabular}{|c|c|c|c|}
\hline Boyutlar & $\mathbf{n}$ & $\overline{\mathbf{x}}$ & SS \\
\hline Okuma & 410 & 3,37 & ,72 \\
\hline Yazma & 410 & 3,12 & ,79 \\
\hline Dinleme & 410 & 3,31 & ,75 \\
\hline Konuşma & 410 & 3,16 & ,89 \\
\hline Özyeterlik Toplam) & 410 & 3,24 & ,69 \\
\hline $\begin{array}{ll}\text { Çok düşük } & \text { (1) } 1.00-1.80 \\
\text { Düşük } & \text { (2) } 1.81-2.60 \\
\text { Orta } & \text { (3) } 2.61-3.40 \\
\text { Yüksek } & \text { (4) } 3.41-4.20 \\
\text { Çok yüksek } & \text { (5) } 4.21-5.00\end{array}$ & & & \\
\hline
\end{tabular}

Tablo 2 incelendiğinde, üniversite hazırlık öğrencilerin toplam İngilizce özyeterlik inançları puan ortalamalarının $\overline{\mathrm{X}}=3,24$, standart saplarının ,69 olduğu görülmektedir. Bu değer öğrencilerin "orta düzey" ingilizce özyeterlik inancını yansıtmaktadır. Boyutlar açısından bakıldığında öğrenciler, en 
yüksek okuma $(\overline{\mathrm{X}}=3,37)$ becerisinde özyeterlik inancına sahip iken bunu sirasıyla dinleme $(\overline{\mathrm{X}}=3,31)$, konuşma $(\overline{\mathrm{X}}=3,16)$ ve yazma $(\overline{\mathrm{X}}=3,12)$ becerileri takip etmiştir.

\section{2. İngilizce Hazırlık Programına Devam Eden Üniversite Öğrencilerinin İngilizce Özyeterlik İnanç Düzeylerinin Kişisel Değișkenlere Göre İncelenmesi}

Araştırmanın ikinci alt amacı doğrultusunda, bazı kişisel özelliklerin İngilizce özyeterlik inancında etkili olup olmadığı belirlenmeye çalışılmıştır. Bu doğrultuda cinsiyet, yaş, okul türü, İngilizce dil seviyesi, akademik başarı, yaşadığı yer, kaldığı yer, bir işte çalışma durumu ve aylık harcama durumu değişkenlerinin İngilizce özyeterlik inancında etkisine ilişsin elde edilen bulgular aşağıda yer almaktadır.

\subsection{Cinsiyet Değişkenine Göre Öğrencilerin İngilizce Özyeterlik İnançları}

Araştırmanın 2. alt amacı doğrultusunda ilk olarak, cinsiyet değişkenine göre İngilizce hazırlık programındaki öğrencilerin İngilizce özyeterlik inançları incelenmiş ve karşılaştırmalara ilişkin yapılan bağımsız t-testi sonuçları Tablo 3'de verilmiştir.

Tablo 3. Cinsiyetlerine göre ögrrencilerin İngilizce özyeterlik inançlarının karşılaştırılmasına ilişkin ttesti sonuçları

\begin{tabular}{|c|c|c|c|c|c|c|c|}
\hline Boyutlar & Cinsiyet & $\mathbf{n}$ & $\overline{\mathbf{x}}$ & SS & $\mathbf{t}$ & $\mathbf{p}$ & Anlam \\
\hline \multirow{2}{*}{ Okuma } & Kadın & 229 & 3,42 & ,71 & \multirow{2}{*}{1,545} & \multirow{2}{*}{, 123} & \multirow{2}{*}{-} \\
\hline & Erkek & 181 & 3,31 &, 73 & & & \\
\hline \multirow{2}{*}{ Yazma } & Kadın & 229 & 3,15 & ,78 & \multirow{2}{*}{,987 } & \multirow{2}{*}{,324 } & \multirow{2}{*}{-} \\
\hline & Erkek & 181 & 3,08 & ,79 & & & \\
\hline \multirow{2}{*}{ Dinleme } & Kadın & 229 & 3,33 & ,76 & \multirow{2}{*}{829} & \multirow{2}{*}{,408 } & \multirow{2}{*}{-} \\
\hline & Erkek & 181 & 3,27 & ,74 & & & \\
\hline \multirow{2}{*}{ Konuşma } & Kadın & 229 & 3,15 & ,89 & \multirow{2}{*}{,- 148} & \multirow{2}{*}{,883 } & \multirow{2}{*}{-} \\
\hline & Erkek & 181 & 3,16 &, 89 & & & \\
\hline \multirow{2}{*}{ Toplam } & Kadın & 229 & 3,26 & ,69 & \multirow{2}{*}{,865 } & \multirow{2}{*}{, 387} & \multirow[b]{2}{*}{-} \\
\hline & Erkek & 181 & 3,21 & 68 & & & \\
\hline
\end{tabular}

Tablo 3'de de görüldüğg̈ gibi, kadın öğrencilerin İngilizce özyeterlik inanç toplam puanları $(\bar{x}=3,26)$ ile erkek öğrencilerin toplam puanlan $(\overline{\mathrm{x}}=3,21)$ arasında fark bulunmaktadır. Gerek İngilizce özyeterlik toplam puanları, gerekse alt boyutlar açısından incelendiğinde; konuşma becerisi dışında tüm alt boyutlarda kadınların erkeklerden daha yüksek iken konuşma boyutunda erkelerin kadınlardan bir puan fazla aritmetik ortalamaya sahip oldukları anlaşılmaktadır. Kadın ve erkekler arasındaki bu farklılığın anlamlı olup olmadığını belirlemek amacıyla yapılan t-testi sonucuna göre, aralarındaki farklılığın $(p<0.05)$ düzeyinde anlamlı olmadığı tespit edilmiştir. Buna göre kadın ve erkek öğrencilerin hem genel, hem de alt boyutlar açısından İngilizce özyeterlik inancının benzer olduğu söylenebilir.

\subsection{Yaş Değişkenine Göre Öğrencilerin İngilizce Özyeterlik İnançları}

Araştırmanın 2. alt amacı doğrultusunda ikinci olarak, yaş değişkenine göre İngilizce hazırlık programındaki öğrencilerin İngilizce özyeterlik inançları incelenmiş ve karşılaştırmalara ilişkin yapılan bağımsız t-testi sonuçları Tablo 4'de verilmiştir.

Tablo 4. Yaş değiş̧kenine göre öğrencilerin İngilizce özyeterlik inançlarının karşılaş̧ııılmasına ilişsin ttesti sonuçları

\begin{tabular}{|c|c|c|c|c|c|c|c|}
\hline Boyutlar & Yaş & $\mathbf{n}$ & $\overline{\mathbf{x}}$ & SS & $\mathbf{t}$ & $\mathbf{p}$ & Anlam \\
\hline \multirow[t]{2}{*}{$\overline{\text { Okuma }}$} & 18 yaş ve altı & 147 & 3,51 &, 70 & \multirow{2}{*}{3,029} & \multirow{2}{*}{,003 } & \multirow[b]{2}{*}{$*$} \\
\hline & 19 yaş ve üzeri & 263 & 3,29 &, 72 & & & \\
\hline \multirow[t]{2}{*}{ Yazma } & 18 yaş ve altı & 147 & 3,12 & ,80 & \multirow{2}{*}{,018 } & \multirow{2}{*}{,985 } & \multirow[t]{2}{*}{ - } \\
\hline & 19 yaş ve üzeri & 263 & 3,12 & ,78 & & & \\
\hline \multirow[t]{2}{*}{ Dinleme } & 18 yaş ve altı & 147 & 3,34 &, 77 & \multirow{2}{*}{,773 } & \multirow{2}{*}{,440 } & \multirow[t]{2}{*}{-} \\
\hline & 19 yaş ve üzeri & 263 & 3,28 &, 74 & & & \\
\hline \multirow[t]{2}{*}{ Konuşma } & 18 yaş ve altı & 147 & 3,17 & ,89 & \multirow{2}{*}{, 303} & \multirow{2}{*}{, 762} & \multirow[t]{2}{*}{-} \\
\hline & 19 yaş ve üzeri & 263 & 3,15 & ,89 & & & \\
\hline \multirow[t]{2}{*}{ Toplam } & 18 yaş ve altı & 147 & 3,29 & ,69 & \multirow{2}{*}{1,100} & \multirow{2}{*}{,272 } & \multirow{2}{*}{ - } \\
\hline & 19 yaş ve üzeri & 263 & 3,21 & ,68 & & & \\
\hline
\end{tabular}


Tablo 4 incelendiğinde, 18 yaş ve altındaki öğrencilerin İngilizce özyeterlik inancı toplam puanları $(\overline{\mathrm{x}}=3,29)$ ile 19 yaş ve üzerindeki öğrencilerin toplam puanları $(\overline{\mathrm{x}}=3,21)$ arasında fark olduğu görülmektedir. Alt boyutlar açısından bakıldığında okuma, dinleme ve konuşma becerilerinin ortalama puanlarında da farklılık gözlenmektedir. 18 yaş ve altındaki öğrencilerin hem bu alt boyutlardaki ortalama puanları hem de İngilizce özyeterlik toplam puanları, 19 yaş ve üzerindeki öğrencilerden daha yüksektir. Bu farklılı̆̆ın anlamlı olup olmadığını belirlemek amacıyla yapılan t-testi sonucuna göre, konuşma boyutu dışındaki boyutların ortalama puanları ve toplam ortalama puanları aralarındaki farklılığın $(\mathrm{p}<0.05)$ düzeyinde anlamlı olmadığı, ancak okuma boyutunda farklılı̆̆ın anlamlı olduğu $(\mathrm{t}=3.029 ; \mathrm{p}<0.05)$ tespit edilmiştir. Buna göre yaş değişkenin okuma boyutu dışında İngilizce özyeterlik inancı üzerinde etkili olmadığı ve 18 yaş ve altındaki öğrencilerin okuma becerisine ilişkin İngilizce özyeterlik inancının 19 yaş ve üzerindeki öğrencilere göre daha yüksek olduğu belirlenmiştir.

\subsection{Okul Türü Değişkenine Göre Öğrencilerin İngilizce Özyeterlik İnançları}

Araştırmanın 2. alt amacı doğrultusunda üçüncü olarak okul türü değişkenine göre İngilizce hazırlık programındaki öğrencilerin İngilizce özyeterlik inançları incelenmiş ve karşılaştırmalara ilişkin yapılan bağımsız t-testi sonuçları Tablo 5'de verilmiştir.

Tablo 5. Okul türü değişkenine göre ögrencilerin İngilizce özyeterlik inançlarının karşılaştırılmasına ilişkin t-testi sonuçlart

\begin{tabular}{|c|c|c|c|c|c|c|c|}
\hline Boyutlar & Okul türü & $\mathbf{n}$ & $\overline{\mathbf{x}}$ & SS & $\mathbf{t}$ & $\mathbf{p}$ & Anlam \\
\hline \multirow{2}{*}{ Okuma } & Devlet üniversitesi & 202 & 3,43 &, 72 & \multirow{2}{*}{1,489} & \multirow{2}{*}{,137 } & \\
\hline & Özel üniversite & 208 & 3,32 &, 72 & & & - \\
\hline \multirow{2}{*}{ Yazma } & Devlet üniversitesi & 202 & 3,06 &, 75 & \multirow{2}{*}{$-1,434$} & \multirow{2}{*}{,152 } & \multirow{2}{*}{-} \\
\hline & Özel üniversite & 208 & 3,17 &, 81 & & & \\
\hline \multirow{2}{*}{ Dinleme } & Devlet üniversitesi & 202 & 3,26 &, 73 & \multirow{2}{*}{$-1,169$} & \multirow{2}{*}{,243 } & \multirow{2}{*}{-} \\
\hline & Özel üniversite & 208 & 3,35 &, 77 & & & \\
\hline \multirow{2}{*}{ Konuşma } & Devlet üniversitesi & 202 & 3,02 &, 84 & \multirow{2}{*}{$-2,988$} & \multirow{2}{*}{,003 } & \multirow{2}{*}{$*$} \\
\hline & Özel üniversite & 208 & 3,28 & ,91 & & & \\
\hline \multirow{2}{*}{ Toplam } & Devlet üniversitesi & 202 & 3,19 & ,66 & \multirow{2}{*}{$-1,301$} & \multirow{2}{*}{,194 } & \multirow{2}{*}{-} \\
\hline & Özel üniversite & 208 & 3,28 & ,71 & & & \\
\hline
\end{tabular}

Tablo 5 incelendiğinde, devlet üniversitesinde öğrenim gören öğrencilerin İngilizce özyeterlik inancı toplam puanları $(\overline{\mathrm{x}}=3,19)$ ile özel üniversitede öğrenim gören öğrencilerin toplam puanları $(\overline{\mathrm{x}}=3,28)$ arasında fark olduğu görülmektedir. Alt boyutlar açısından bakıldığında da okuma, yazma, dinleme ve konuşma becerilerinin ortalama puanlarında da farklık gözlenmektedir. Özel üniversitede öğrenim gören öğrencilerin hem İngilizce özyeterlik inancı toplam ortalama puanları hem de yazma, dinleme, konuşma boyutlardaki İngilizce özyeterlik inancı ortalama puanları, devlet üniversitelerindeki öğrencilerden daha yüksektir. Okuma alt boyutunda ise devlet üniversitelerindeki öğrencilerin puan ortalamalarının daha yüksek olduğu görülmektedir. Bununla birlikte bu farklılığın anlamlı olup olmadığını belirlemek amacıyla yapılan t-testi sonucuna göre; konuşma boyutu dışındaki boyutların ortalama puanları ve toplam ortalama puanları aralarındaki farklılığın $(\mathrm{p}<0.05)$ düzeyinde anlamlı olmadığı, konuşma boyutunda ise anlamlı farkl11ık olduğu $(\mathrm{t}=-2,988 ; \mathrm{p}<0.05)$ tespit edilmiştir. Buna göre okul türü değişkenin konuşma boyutu dışında İngilizce özyeterlik inancı üzerinde etkili olmadığı ve özel üniversitede öğrenim gören öğrencilerin konuşma becerisine ilişkin İngilizce özyeterlik inancının devlet üniversitesindeki öğrencilere göre daha yüksek olduğu belirlenmiştir.

\subsection{Akademik Başarı Değişkenine Göre Öğrencilerin İngilizce Özyeterlik İnançları}

Araştırmanın 2. alt amacı doğrultusunda dördüncü olarak akademik başarı değişkenine göre İngilizce hazırlık programındaki öğrencilerin İngilizce özyeterlik inançlanı incelenmiş ve karşılaştırmalara ilişkin yapılan bağımsız t-testi sonuçları Tablo 6'da verilmiştir. 
İngilizce Hazırlık Programına Devam Eden Üniversite Öğrencilerinin İngilizce Özyeterlik İnançlarının İncelenmesi

Tablo 6. Akademik başarı değişkenine göre öğrencilerin İngilizce özyeterlik inançlarının karşılaştırılmasına iliş̧kin t-testi sonuçları

\begin{tabular}{|c|c|c|c|c|c|c|c|}
\hline Boyutlar & Akademik Başarı & n & $\overline{\mathbf{x}}$ & SS & $\mathbf{t}$ & p & Anlam \\
\hline \multirow{2}{*}{ Okuma } & Orta ve alt1 & 168 & 3,18 & ,69 & \multirow{2}{*}{$-4,517$} & \multirow{2}{*}{,000 } & \multirow{2}{*}{$*$} \\
\hline & İyi ve çok iyi & 242 & 3,50 &, 71 & & & \\
\hline \multirow{2}{*}{ Yazma } & Orta ve alt1 & 168 & 2,92 &, 80 & \multirow{2}{*}{$-4,396$} & \multirow{2}{*}{,000 } & \multirow{2}{*}{$*$} \\
\hline & İyi ve çok iyi & 242 & 3,26 &, 75 & & & \\
\hline \multirow{2}{*}{ Dinleme } & Orta ve alt1 & 168 & 3,14 &, 71 & \multirow{2}{*}{$-3,691$} & \multirow{2}{*}{,000 } & \multirow{2}{*}{$*$} \\
\hline & İyi ve çok iyi & 242 & 3,42 & ,76 & & & \\
\hline \multirow{2}{*}{ Konuşma } & Orta ve alt 1 & 168 & 2,96 & ,89 & \multirow{2}{*}{$-3,869$} & \multirow{2}{*}{,000 } & \multirow{2}{*}{$*$} \\
\hline & İyi ve çok iyi & 242 & 3,29 & 86 & & & \\
\hline \multirow{2}{*}{ Toplam } & Orta ve altı & 168 & 3,05 & ,66 & \multirow{2}{*}{$-4,733$} & \multirow{2}{*}{, 000} & \multirow{2}{*}{$*$} \\
\hline & İyi ve çok iyi & 242 & 3,37 & ,68 & & & \\
\hline
\end{tabular}

Tablo 6 incelendiğinde, akademik başarısı orta ve altı düzeyde olan öğrencilerin İngilizce özyeterlik inancı toplam puanları $(\overline{\mathrm{x}}=3,05)$ ile iyi ve çok iyi düzeyde olan öğrencilerin toplam puanları $(\overline{\mathrm{x}}=3,28)$ arasında fark olduğu görülmektedir. Alt boyutlar açısından bakıldığında da benzer şekilde tüm alt boyutların ortalama puanlarında farklık gözlenmektedir. Akademik başarısı orta ve altı düzeyde olan öğrencilerin hem İngilizce özyeterlik inancı toplam ortalama puanları, hem de okuma, yazma, dinleme, ve konuşma boyutlardaki İngilizce özyeterlik inancı ortalama puanları, iyi ve çok iyi düzeydeki öğrencilerden daha düşüktür. Bu farklılığın anlamlı olup olmadığını belirlemek amacıyla yapılan t-testi sonucuna göre; tüm boyutlarda ve toplam İngilizce özyeterlik inancında farklılığın $(\mathrm{p}<0.05)$ düzeyinde anlamlı olduğu tespit edilmiştir. Buna göre akademik başarı değişkenin öğrencilerin İngilizce özyeterlik inancı üzerinde etkili olduğu ve akademik açıdan başarılı olanların, İngilizce özyeterlik açısından kendilerine daha çok inandıkları söylenebilir.

\section{5. İngilizce Dil Seviyesi Değişkenine Göre Öğrencilerin İngilizce Özyeterlik İnançları}

Araştırmanın 2. alt amacı doğrultusunda beşinci olarak İngilizce dil seviyesi değişkenine göre İngilizce hazırlık programındaki öğrencilerin İngilizce özyeterlik inançları incelenmiş ve karşılaştırmalara ilişkin yapılan tek yönlü varyans analizi (ANOVA) sonuçları Tablo 7'de verilmiştir.

Tablo 7. Ingilizce dil seviyesi değişkenine göre öğrencilerin İngilizce özyeterlik inançlarının karşılaş̧tırılmasına iliş̧kin tek yönlü varyans analizi (ANOVA)sonuçları

\begin{tabular}{|c|c|c|c|c|c|c|c|}
\hline Boyutlar & Dil seviyesi & $\mathrm{n}$ & $\overline{\mathbf{x}}$ & SS & $\mathbf{F}$ & p & Anlam \\
\hline \multirow{4}{*}{ Okuma } & $\mathrm{A} 1$ & 84 & 2,97 &, 81 & \multirow{4}{*}{15,589} & \multirow{4}{*}{, 000} & \multirow{4}{*}{$\begin{array}{l}\text { A1-A2 } \\
\text { A1-B1 } \\
\text { A1-B2 } \\
\text { A2-B1 }\end{array}$} \\
\hline & A2 & 137 & 3,35 & ,66 & & & \\
\hline & B1 & 86 & 3,62 & ,68 & & & \\
\hline & B2 & 103 & 3,53 & ,59 & & & \\
\hline \multirow{4}{*}{ Yazma } & A1 & 84 & 2,75 & ,82 & \multirow{4}{*}{20,188} & \multirow{4}{*}{,000 } & \multirow{4}{*}{$\begin{array}{l}\mathrm{A} 1-\mathrm{B} 1 \\
\mathrm{~A} 1-\mathrm{B} 2 \\
\mathrm{~A} 2-\mathrm{B} 2\end{array}$} \\
\hline & $\mathrm{A} 2$ & 137 & 2,97 & ,70 & & & \\
\hline & B1 & 86 & 3,25 & ,73 & & & \\
\hline & B2 & 103 & 3,52 & ,71 & & & \\
\hline \multirow{4}{*}{ Dinleme } & $\mathrm{A} 1$ & 84 & 2,88 &, 85 & \multirow{4}{*}{15,514} & \multirow{4}{*}{,000 } & \multirow{4}{*}{$\begin{array}{l}\mathrm{A} 1-\mathrm{A} 2 \\
\mathrm{~A} 1-\mathrm{B} 1 \\
\mathrm{~A} 1-\mathrm{B} 2 \\
\mathrm{~A} 2-\mathrm{B} 2\end{array}$} \\
\hline & $\mathrm{A} 2$ & 137 & 3,29 & ,63 & & & \\
\hline & B1 & 86 & 3,45 & ,74 & & & \\
\hline & B2 & 103 & 3,56 & ,67 & & & \\
\hline \multirow{4}{*}{ Konuşma } & $\mathrm{A} 1$ & 84 & 2,64 & ,86 & \multirow{4}{*}{30,567} & \multirow{4}{*}{,000 } & A1-A2 \\
\hline & $\mathrm{A} 2$ & 137 & 2,99 & 80 & & & A1-B1 \\
\hline & B1 & 86 & 3,26 & 81 & & & $\begin{array}{l}\text { A1-B2 } \\
\text { A2-B2 }\end{array}$ \\
\hline & B2 & 103 & 3,71 & ,76 & & & $\mathrm{B} 1-\mathrm{B} 2$ \\
\hline \multirow{2}{*}{ Toplam } & $\mathrm{A} 1$ & 84 & 2,81 & ,76 & \multirow{2}{*}{25,867} & \multirow{2}{*}{, 000} & A1-A2 \\
\hline & A2 & 137 & 3,15 &, 58 & & & A1-B1 \\
\hline
\end{tabular}




$\begin{array}{ccccc}\text { B1 } & 86 & 3,40 & , 63 & \text { A1-B2 } \\ \text { B2 } & 103 & 3,58 & , 57 & \text { A2-B1 } \\ \text { A2-B2 }\end{array}$

Tablo 7'de de görüldüğü gibi, dil seviyesi farklı olan öğrencilerin hem genel İngilizce özyeterlik inancı, hem de tüm boyutlara ilişkin özyeterlik inancı puan ortalamaları arasında $(\mathrm{p}<0.05)$ düzeyinde anlamlı farklılık vardır. İngilizce dil seviyelerinin tüm boyutlarında (okuma boyutunda B1 ve B2 hariç) ve toplamda puan ortalamaları incelendiğinde düşük dil seviyesine sahip olan öğrencilerin İngilizce özyeterlik inanç puanlarının daha düşük, yüksek dil seviyesindekilerin daha yüksek puan aldıkları gözlenmektedir. İngilizce özyeterlik inançlarındaki farklılığın kaynağını belirlemek amacıyla yapılan Scheffe testi sonucuna göre araştırma kapsamında en düşük dil seviyesi olan A1 düzeyindeki ögrencilerin, diğer dil seviyesindekilerden daha düşük İngilizce özyeterlik inançlarına sahip olmaları bu farklılığın kaynağını oluşturmaktadır. Elde edilen bulgulara göre, İngilizce dil seviyesi değişkenin öğrencilerin İngilizce özyeterlik inancı üzerinde etkili olduğu ve öğrencilerin dil seviyesi arttıkça İngilizce özyeterlik inancının da arttığı söylenebilir.

\subsection{Yaşanan Yer Değişkenine Göre Öğrencilerin İngilizce Özyeterlik İnançları}

Araştırmanın 2. alt amacı doğrultusunda altıncı olarak yaşanan yer değişkenine göre İngilizce hazırlık programındaki öğrencilerin İngilizce özyeterlik inançları incelenmiş ve karşılaş̧ırmalara ilişkin yapılan bağımsız t-testi sonuçları Tablo 8'da verilmiştir.

Tablo 8. Yaşanan yer değişkenine göre öğrencilerin İngilizce özyeterlik inançlarının karşılaştırılmasına ilişkin t-testi sonuçları

\begin{tabular}{|c|c|c|c|c|c|c|c|}
\hline Boyutlar & Yaşanan Yer & $\mathbf{n}$ & $\overline{\mathbf{x}}$ & SS & $\mathbf{t}$ & p & Anlam \\
\hline \multirow{2}{*}{ Okuma } & Büyükşehir & 349 & 3,41 &, 70 & \multirow{2}{*}{2,745} & \multirow{2}{*}{,006 } & \multirow{2}{*}{$*$} \\
\hline & Diğer & 61 & 3,14 & ,78 & & & \\
\hline \multirow{2}{*}{ Yazma } & Büyükşehir & 349 & 3,13 & ,77 & \multirow{2}{*}{, 820} & \multirow{2}{*}{,413 } & \multirow{2}{*}{ - } \\
\hline & Diğer & 61 & 3,04 & ,86 & & & \\
\hline \multirow{2}{*}{ Dinleme } & Büyükşehir & 349 & 3,35 & ,75 & \multirow{2}{*}{2,597} & \multirow{2}{*}{010} & \multirow{2}{*}{$*$} \\
\hline & Diğer & 61 & 3,08 &, 72 & & & \\
\hline \multirow{2}{*}{ Konuşma } & Büyükşehir & 349 & 3,18 & ,90 & \multirow{2}{*}{1,433} & \multirow{2}{*}{, 153} & \multirow{2}{*}{ - } \\
\hline & Diğer & 61 & 3,01 & ,83 & & & \\
\hline \multirow{2}{*}{ Toplam } & Büyükşehir & 349 & 3,27 &, 68 & \multirow{2}{*}{2,126} & \multirow{2}{*}{,034 } & \multirow{2}{*}{$*$} \\
\hline & Diğer & 61 & 3,07 &, 70 & & & \\
\hline
\end{tabular}

Tablo 8 incelendiğinde, büyükşehirde yaşayan öğrencilerin İngilizce özyeterlik inancı toplam puanları $(\bar{x}=3,27)$ ile büyükşehir haricinde başka bir yerde yaşayan öğrencilerin toplam puanları $(\overline{\mathrm{x}}=3,07)$ arasında fark olduğu görülmektedir. Alt boyutlar açısından incelendiğinde de benzer şekilde tüm alt boyutların ortalama puanlarında farklılık gözlenmektedir. Büyükşsehirlerde yaşayan öğrencilerin hem İngilizce özyeterlik inancı toplam ortalama puanları, hem de tüm alt boyutlardaki İngilizce özyeterlik inancı ortalama puanları, büyükşehir haricinde başka bir yerde (ilçe, kasaba, köy vb) yaşayanlardan daha yüksektir. Bu farklılığın anlamlı olup olmadığını belirlemek amacıyla yapılan t-testi sonucuna göre; okuma ve dinleme boyutu ile toplam İngilizce özyeterlik inancında farklılığın $(p<0.05)$ düzeyinde anlamlı olduğu tespit edilmiştir. Buna göre öğrencilerin yaşadığı yer değişkenin öğrencilerin İngilizce özyeterlik inancı üzerinde etkili olduğu ve büyükşehirde yaşayan öğrencilerin okuma ve dinleme becerilerinde daha yüksek İngilizce özyeterlik inancına sahip oldukları söylenebilir.

\section{7. Çalışma Durumu Değişkenine Göre Öğrencilerin İngilizce Özyeterlik İnançları}

Araştırmanın 2. alt amacı doğrultusunda yedinci olarak çalışma durumu değişkenine göre İngilizce hazırlık programındaki öğrencilerin İngilizce özyeterlik inançları incelenmiş ve karşılaştırmalara ilişkin yapılan bağımsız t-testi sonuçları Tablo 9'da verilmiştir. 
İngilizce Hazırlık Programına Devam Eden Üniversite Öğrencilerinin İngilizce Özyeterlik İnançlarının İncelenmesi

Tablo 9. Çalışma durumu değişkenine göre öğrencilerin Ingilizce özyeterlik inançlarının karşıllaștırılmasına ilişskin t-testi sonuçları

\begin{tabular}{|c|c|c|c|c|c|c|c|}
\hline Boyutlar & Çalışma Durumu & $\mathbf{n}$ & $\overline{\mathbf{x}}$ & SS & $\mathbf{t}$ & $\mathbf{p}$ & Anlam \\
\hline \multirow{2}{*}{ Okuma } & Evet & 49 & 3,29 & ,76 & \multirow{2}{*}{,- 873} & \multirow{2}{*}{,383 } & \multirow{2}{*}{-} \\
\hline & Hayır & 361 & 3,38 & ,71 & & & \\
\hline \multirow{2}{*}{ Yazma } & Evet & 49 & 3,13 & ,75 & \multirow{2}{*}{,132 } & \multirow{2}{*}{,895 } & \multirow{2}{*}{-} \\
\hline & Hayır & 361 & 3,12 & ,79 & & & \\
\hline \multirow{2}{*}{ Dinleme } & Evet & 49 & 3,27 & ,77 & \multirow{2}{*}{, 853} & \multirow{2}{*}{ 688 } & \multirow{2}{*}{-} \\
\hline & Hayır & 361 & 3,31 & ,75 & & & \\
\hline \multirow{2}{*}{ Konuşma } & Evet & 49 & 3,26 & ,89 & \multirow{2}{*}{,764 } & \multirow{2}{*}{,404 } & \multirow{2}{*}{-} \\
\hline & Hayır & 361 & 3,14 & ,89 & & & \\
\hline \multirow{2}{*}{ Toplam } & Evet & 49 & 3,24 & ,67 & \multirow{2}{*}{,- 031} & \multirow{2}{*}{,976 } & \multirow{2}{*}{-} \\
\hline & Hayır & 361 & 3,24 & ,69 & & & \\
\hline
\end{tabular}

Tablo 9'da da görüldüğü gibi, herhangi bir işte çalışan öğrenciler ile çalışmayan öğrencilerin İngilizce özyeterlik inanç toplam puanları $(\overline{\mathrm{x}}=3,24)$ arasında fark bulunmamaktadır. İngilizce özyeterlik puan ortalamaları, alt boyutlarda farklılık göstermekle birlikte bu farkın anlamlı olup olmadığını belirlemek amaciyla yapılan t-testi sonucuna göre, farklılığın $(\mathrm{p}<0.05)$ düzeyinde anlamlı olmadı̆̆ 1 tespit edilmiştir. Buna göre öğrencilerin çalışma durumu değişkeninin onların ingilizce özyeterlik inancını etkilemediği anlaşılmaktadır.

\subsection{Kalınan Yer Değişkenine Göre Öğrencilerin İngilizce Özyeterlik İnançları}

Araştırmanın 2. alt amacı doğrultusunda sekizinci olarak kalınan yer değişkenine göre İngilizce hazırlık programındaki öğrencilerin İngilizce özyeterlik inançları incelenmiş ve karşılaştırmalara ilişkin yapılan tek yönlü varyans analizi (ANOVA) sonuçları Tablo 10'da verilmiştir.

Tablo 10. Kalınan yer değişkenine göre öğrencilerin İngilizce özyeterlik inançlarının karşılaşstırılmasına ilişkin tek yönlü varyans analizi (ANOVA)sonuçları

\begin{tabular}{|c|c|c|c|c|c|c|c|}
\hline Boyutlar & Kalınan Yer & $\mathbf{n}$ & $\overline{\mathbf{x}}$ & SS & $\mathbf{F}$ & $\mathbf{p}$ & Anlam \\
\hline \multirow{3}{*}{ Okuma } & Ailesi ile & 252 & 3,43 &, 70 & \multirow{3}{*}{2,284} & \multirow{3}{*}{,103 } & \multirow{3}{*}{-} \\
\hline & Yurtta & 112 & 3,28 & ,72 & & & \\
\hline & Diğer & 46 & 3,28 &, 81 & & & \\
\hline \multirow{3}{*}{ Yazma } & Ailesi ile & 252 & 3,19 &, 75 & \multirow{3}{*}{3,009} & \multirow{3}{*}{, 050} & \multirow{3}{*}{-} \\
\hline & Yurtta & 112 & 2,97 &, 83 & & & \\
\hline & Diğer & 46 & 3,10 &, 82 & & & \\
\hline \multirow{3}{*}{ Dinleme } & Ailesi ile & 252 & 3,35 & ,76 & \multirow{3}{*}{2,137} & \multirow{3}{*}{,119 } & \multirow{3}{*}{-} \\
\hline & Yurtta & 112 & 3,18 &, 74 & & & \\
\hline & Diğer & 46 & 3,34 &, 74 & & & \\
\hline \multirow{3}{*}{ Konuşma } & Ailesi ile & 252 & 3,22 &, 88 & \multirow{3}{*}{1,777} & \multirow{3}{*}{, 171} & \multirow{3}{*}{-} \\
\hline & Yurtta & 112 & 3,03 & ,87 & & & \\
\hline & Diğer & 46 & 3,12 & ,96 & & & \\
\hline \multirow{3}{*}{ Toplam } & Ailesi ile & 252 & 3,30 & 67 & \multirow{3}{*}{2,839} & \multirow{3}{*}{, 060} & \multirow{3}{*}{-} \\
\hline & Yurtta & 112 & 3,12 & ,69 & & & \\
\hline & Diğer & 46 & 3,21 & ,76 & & & \\
\hline
\end{tabular}

Tablo 10 incelendiğinde, öğrencilik yaşamında ailesiyle birlikte kalan öğrencilerin İngilizce özyeterlik inancı toplam puanları $(\overline{\mathrm{x}}=3,30)$ ile yurtta kalan öğrencilerin $(\overline{\mathrm{x}}=3,12)$ ve bunların dışında (öğrenci evi ya da akrabasıyla birlikte vb.) başka bir yerde $(\overline{\mathrm{x}}=3,21)$ yaşamına devam edenlerin toplam puanları arasında fark olduğu görülmektedir. Alt boyutlar açısından incelendiğinde de benzer şekilde tüm alt boyutların ortalama puanlarında ailesiyle birlikte yaşayanların lehine farklılık gözlenmektedir. $\mathrm{Bu}$ farklılığın anlamlı olup olmadığını belirlemek amacıyla yapılan tek yönlü varyans analizi sonucuna göre, gerek toplam puan ortalamalarına gerekse alt boyutlara ilişkin puan ortalamalarında bu farklılığın $(\mathrm{p}<0.05)$ düzeyinde anlamlı olmadığı tespit edilmiştir. Buna göre öğrencilerin ailesiyle birlikte, yurtta, öğrenci 
evinde ya da akrabasıyla birlikte yaşıyor olmasının İngilizce özyeterlik inancını üzerinde bir etkisi olmadığı söylenebilir.

\subsection{Aylık Harcama Değişkenine Göre Öğrencilerin İngilizce Özyeterlik İnançları}

Araştırmanın 2. alt amacı doğrultusunda dokuzuncu olarak aylık harcama değişkenine göre İngilizce hazırlık programındaki öğrencilerin İngilizce özyeterlik inançları incelenmiş ve karşılaştırmalara ilişkin yapılan tek yönlü varyans analizi (ANOVA) sonuçları Tablo 11'de verilmiştir.

Tablo 11. Aylık harcama değişkenine göre öğrencilerin İngilizce özyeterlik inançlarının karşılaş̧tırılmasina iliş̧kin tek yönlü varyans analizi (ANOVA) sonuçları

\begin{tabular}{|c|c|c|c|c|c|c|c|}
\hline Boyutlar & Aylık Harcama & $\mathbf{N}$ & $\overline{\mathbf{x}}$ & SS & $\mathbf{F}$ & $\mathbf{p}$ & Anlam \\
\hline \multirow{5}{*}{ Okuma } & 500 ve alt 1 & 96 & 3,45 & ,68 & \multirow{5}{*}{1,877} & \multirow{5}{*}{144} & \multirow{5}{*}{-} \\
\hline & $501-750$ & 137 & 3,30 & ,70 & & & \\
\hline & 751- 1000 & 75 & 3,52 & ,78 & & & \\
\hline & $1001-1500$ & 53 & 3,33 & 69 & & & \\
\hline & 1501 ve üzeri & 49 & 3,24 & ,74 & & & \\
\hline \multirow{5}{*}{ Yazma } & 500 ve alt 1 & 96 & 3,25 & ,69 & \multirow{5}{*}{1,471} & \multirow{5}{*}{,210 } & \multirow{5}{*}{-} \\
\hline & $501-750$ & 137 & 3,02 & ,79 & & & \\
\hline & $751-1000$ & 75 & 3,19 & ,91 & & & \\
\hline & $1001-1500$ & 53 & 3,04 & ,74 & & & \\
\hline & 1501 ve üzeri & 49 & 3,10 & ,78 & & & \\
\hline \multirow{5}{*}{ Dinleme } & 500 ve altı & 96 & 3,39 & ,67 & \multirow{5}{*}{1,668} & \multirow{5}{*}{, 157} & \multirow{5}{*}{-} \\
\hline & $501-750$ & 137 & 3,23 & ,75 & & & \\
\hline & 751- 1000 & 75 & 3,42 & ,86 & & & \\
\hline & $1001-1500$ & 53 & 3,35 & ,69 & & & \\
\hline & 1501 ve üzeri & 49 & 3,15 & ,78 & & & \\
\hline \multirow{5}{*}{ Konuşma } & 500 ve alt 1 & 96 & 3,21 & ,78 & \multirow{5}{*}{2,236} & \multirow{5}{*}{,064 } & \multirow{5}{*}{-} \\
\hline & $501-750$ & 137 & 3,01 & ,95 & & & \\
\hline & $751-1000$ & 75 & 3,36 & ,94 & & & \\
\hline & $1001-1500$ & 53 & 3,24 & ,82 & & & \\
\hline & 1501 ve üzeri & 49 & 3,07 & ,86 & & & \\
\hline \multirow{5}{*}{ Toplam } & 500 ve alt 1 & 96 & 3,32 & ,59 & \multirow{5}{*}{2,056} & \multirow{5}{*}{,086 } & \multirow{5}{*}{-} \\
\hline & $501-750$ & 137 & 3,14 & ,71 & & & \\
\hline & $751-1000$ & 75 & 3,37 & ,77 & & & \\
\hline & $1001-1500$ & 53 & 3,24 & ,63 & & & \\
\hline & 1501 ve üzeri & 49 & 3,14 & ,69 & & & \\
\hline
\end{tabular}

Tablo 11 incelendiğinde, aylık harcamaları açısından öğrencilerin İngilizce özyeterlik inancı toplam puanları ve alt boyutlara ilişkin puan ortalamaları arasında, 751-1000 TL harcama yapanların lehine farklılık olduğu görülmektedir. Bu farklılığın anlamlı olup olmadığını belirlemek amacıyla yapılan tek yönlü varyans analizi sonucuna göre, gerek toplam puan ortalamalarına gerekse alt boyutlara ilişkin puan ortalamalarında bu farklılığın $(\mathrm{p}<0.05)$ düzeyinde anlamlı olmadığı tespit edilmiştir. Buna göre öğrencilerin aylık harcamalarının bir diğer ifade ile ekonomik durumların İngilizce özyeterlik inancını üzerinde bir etkisi olmadığı söylenebilir. 


\section{SONUÇ VE TARTIŞMA}

Araştırmada ulaşılan ilk sonuç üniversite hazırlık programındaki öğrencilerinin İngilizce özyeterlik inançlarının orta seviyede olduğu sonucudur. Bu sonuç öğrencilerin özyeterlik inançlarının istenilen düzeyde olmadığını göstermektedir. Öğrenciler İngilizce dilini öğrenmeyi başarabilme konusunda kendilerini çok yeterli görmemektedir. İngilizce öğrenmek için yüksek düzeyde azim ve kararlılığa sahip değildirler. Literatürdeki bazı araştırmalar da bu sonuçla paralellik göstermektedir (Şener ve Erol, 2017; Kaya, 2016; Karanfil, 2015; Oğuz ve Akkaş Baysal, 2015; Gömleksiz, 2014). Öğrencilerin İngilizce özyeterlik inançları okuma, yazma, dinleme ve konuşma becerileri açısından karşılaştırıldığında ise öğrenciler bu becerilerin tümünde yine orta düzeyde özyeterlik inancına sahip olmakla birlikte, en yüksek okuma becerisinde kendilerine inanmaktadırlar. Okuma becerisini sırasıyla dinleme, konuşma ve yazma becerileri takip etmektedir. Yani öğrenciler kendilerinin en az yazma becerisinde başarabileceklerine inanmaktadırlar. Özyeterlik inancının okuma becerisinde yüksek çıkma sebebi algılayıcı becerilerden biri oluşu ve öğrencilerin okuma becerilerini destekleyen uyarıcılarla daha sık karşılaşması ile açıklanabilir. Bandura'ya (1994) göre bireyin doğrudan yaşantıları özyeterlik inancını oluşturan en etkili kaynaktır. Okuma becerisini destekleyen uyarıcılarla daha sık karșılan ögrencilerin, bu konuda kendini daha yeterli hissetme ihtimali de yüksektir. Yazma becerisinde özyeterlik inancinın düşük çıkması ise üretimsel becerilerden biri olması ile açılanabilir. Üretimsel beceriler olan konuşma ve yazma becerileri, bireyin iletişimsel becerilerini kullanarak bir mesaj üretmesini gerektirir. Dolayısıyla konuşma ve yazma becerilerinde, okuma ve dinleme becerilerinden farklı olarak öğrencinin aktif olması ve üretim yapması ihtiyacı doğmaktadır. Özellikle yazma becerisinde içerik, düzen, fikirlerin akış ve uyumu, dil bilgisi kuralları, kelime seçimi ve dağarcığı ile noktalama işaretleri gibi detayların hepsinin birlikte işe koşularak üretim yapılması bu beceride özyeterlik inancının düşük olmasına neden olmuş olabilir. Karanfil (2015) de İngilizce hazırlık öğrencilerinin özyeterlik inançlarını incelemiş, öğrencilerin okuma becerisine ilişkin öz yeterlik inançlarının en yüksek düzeyde, yazma becerisine ilişkin özyeterlik inançlarının ise en düşük seviyede olduğu sonucuna ulaşmıştır. Benzer şekilde Taşdemir (2018) lise öğrencilerinin İngilizce özyeterlik inançlarının en yüksek okuma becerisinde, en düşük ise konuşma ve yazma becerisinde sahip olduğunu ortaya çıkarmıştır.

Araştırmanın ikinci alt problemi doğrultusunda İngilizce hazırlık programına devam eden öğrencilerin cinsiyeti, yaşı, okul türü, İngilizce dil seviyesi, akademik başarısı, yaşadıkları yer, kaldıkları yer, bir işte çalışma durumları ve aylık harcama durumlarının İngilizce özyeterlik inançları üzerindeki etkisi belirlenmeye çalışılmıştır. Bu değişkenlerden akademik başarı, İngilizce dil seviyesi ve yaşanan yer dışındaki değişkenlerin öğrencilerin İngilizceye yönelik genel özyeterlik inancında etkili olmadığı sonucuna ulaşılmıştır. Bu bağlamda ulaşılan ilk sonuç cinsiyetin İngilizce özyeterlik üzerinde etkili olmadığı sonucudur. Yani hem kadın hem de erkek öğrenciler benzer düzeyde İngilizce özyeterliğe sahiptir. İlgili araştırmalar incelendiğinde bu sonucu destekleyen pek çok çalışma olduğu gözlenmektedir (Adelodun ve Asiru, 2015; Güler Oğuz, 2019; Güç, 2019; Sevimbay, 2016; Baloğlu, 2011; Sani ve Zain, 2011). Örneğin, Uygur (2010) da İngiliz dili eğitimi lisans öğrencilerinin özyeterlik inançlarını çeşitli değişkenlere göre incelediği araştırmasında, kadın ve erkek öğrencilerin özyeterlik inançları arasında anlamlı bir fark bulunmadığını belirtmiştir. Yapılan bazı çalışmalarda ise İngilizce özyeterlik inancının kadın öğrencilerin lehine daha yüksek olduğu görülmektedir (Arslan, 2018; Güneri, 2018; Şenel ve Erol, 2017; Coşkun,2017; Huang, 2013). Alanyazında mevcut çalışmanın bulguları ile örtüşmeyen araştırmalara da rastlamak mümkündür (Necan, 2019; Akbay ve Gizir, 2010). Erdoğdu ve Yüzbaş (2018), lise öğrencileri ile yapmış oldukları çalışmada erkek öğrencilerin özyeterlik inançlarının kız öğrencilerden daha yüksek olduğu sonucuna ulaşmıştır. Ergür'ün (2016) İngiliz Dilbilimi ve İngilizce Mütercim Tercümanlık bölümlerinde okuyan öğrenciler ile gerçekleştirdiği çalışmada yine erkek öğrencilerin özyeterlik inançlarının daha yüksek olduğu görülmektedir. Ortaya çıkan özyeterlik inancı arasındaki bu farklılıkların öğrencilerin cinsiyetlerine yüklediklenen roller neticesinde geliştiği söylenebilir (Akbay ve Gizir, 2010). Toplumun, bireylerin cinsiyetlerine yönelik sahip oldukları fikirler hem meslek seçiminde hem de özyeterlik inancı üzerinde etkili olabilmektedir (Schunk ve Pajares, 2001). Erkek egemen kültürlerde, erkeklerin daha başarılı oldukları ve zorlukların üzerinden daha kolay gelebilecekleri fikri yaygınken, bazı kültürlerde ise cinsiyet faktörünün fark yaratmadığı, bireyin kapasitesinin ve çalışma azminin belirleyici olduğu fikri yaygın olabilmektedir. 
Araştırmada incelenen diğer bir kişisel değişken yaştır. Araştırmada 18 yaş ve altındaki öğrenciler ile 19 yaş ve üzerindeki öğrencilerin toplam İngilizce özyeterlik inançları arasında anlamlı bir fark bulunmadığı tespit edilmiştir. Buna göre üniversitede hazırlık programında öğrenim gören öğrencilerin yaşı, onların genel anlamda İngilizce özyeterlilik inancını etkilememektedir. Bununla birlikte okuma becerisinde 18 yaş ve altında olan öğrencilerin İngilizce özyeterlik inancının 19 yaş ve üzerinde olan öğrencilerden daha yüksek olduğu belirlenmiştir. Alanyazında öğrencilerin yaş ve özyeterlik inançlarını ele alan çalışmalar (Şubaş, 2018; Uçar, 2012; Netz ve Raviv; 2004) bulunmaktadır. Jenks (2004) İngilizce özyeterlik ve yaş arasındaki ilişkiyi incelediği çalışmasında, yaşın özyeterlik inancı üzerinde etkili olmadığı sonucuna ulaşmıştır. Buna paralel olarak Pamuk (2014) da İngilizce yazma sınıflarında özyeterlik, tutum ve başarı arasındaki ilişkiyi ele aldığı çalışmasında çeşitli değişkenlerin etkilerini incelemiş, öğrencilerin yaşlarının özyeterlik inancı üzerinde bir etkisi olmadığını belirlemiştir. Yapılan bu araştırmalar, bu çalışmanın bulgusunu destekler niteliktedir.

Araştırmada incelenen bir başka kişisel değişken okul türüdür. Araştırmanın bulgularına göre İngilizce hazırlık programına devam eden öğrencilerin genel İngilizce özyeterlik inançları, okul türüne göre farklılaşmamaktadır. Buna göre öğrencilerin devlet üniversitesinde ya da özel üniversitede öğrenim görmesi onları özyeterlik inancını etkilememektedir. Ancak konuşma becerisinde özel üniversitede öğrenim gören öğrencilerin İngilizce özyeterlik inançlarının daha yüksek olduğu tespit edilmiștir. Bu durum, özel üniversitelerdeki hazırlık okullarında genellikle daha fazla sayıda yabancı okutman bulunmasından kaynaklanabilir. Öğrenciler, ana dili İngilizce olan öğretmenlere karşı daha olumlu tutumlar sergileyip diğer öğretmenlere göre daha iyi bir eğitim aldıkları inancına sahip olabilmektedir (Kelch ve Santana-Williamson, 2002). Öğrencilerin İngilizceyi ana dili İngilizce olan bir okutman ile iletişim kurarak öğrenmeleri konuşma becerilerindeki özyeterlik inançlarını olumlu yönde etkilemiş olabilir.

Araştırmada ele alınan bir diğer değişken İngilizce dil seviyesidir. Elde edilen bulgulara göre ögrencilerin İngilizce seviyesi ile İngilizce özyeterlik inançları arasında anlamlı bir fark bulunmaktadır. Buna göre A1 seviyesindeki öğrencilerin İngilizce özyeterlik inançları A2 sevisindeki öğrencilerden, A2 sevisindeki öğrencilerin B1 seviyesindekilerden, B1 seviyesindeki öğrencilerin de B2 seviyesindeki öğrencilerden daha yüksektir. Yani seviye yükseldikçe özyeterlik inancı da artmaktadır. Bu durum ögrencilerin İngilizce bilgi ve beceri seviyelerinin artmasının kendi kapasitelerine duydukları güveni de arttırmasıyla açıklanabilir. Jenks (2004), yaptığı araştırmada ileri seviyedeki öğrencilerin başlangıç seviyesindeki öğrencilere göre çok daha yüksek özyeterlik inancına sahip olduğu belirlemiştir. Tılfarlığlu ve Cinkaya (2009) da hazırlık öğrencilerinin İngilizce özyeterliklerini, İngilizce dil seviyesi ve başarıları açısından incelediği çalışmalarında; öğrencilerin İngilizce özyeterlik inançlarının başlangıç, orta ve ileri seviye gruplarının üçünde de farklılık gösterdiğini, başlangıç seviyesindeki öğrencilerin İngilizce özyeterlik inançlarının ileri seviye grubundaki öğrencilere göre oldukça düşük olduğunu vurgulamaktadır. Yapılan bu araştırmaların bulguları bu çalışmanın bulgusu ile paralellik göstermektedir.

Akademik başarı, araştırmada incelenen diğer bir kişisel değişkendir. Elde edilen bulgulara göre öğrencilerin akademik başarıları, İngilizce özyeterlik inançlarını etkilemektedir. Akademik başarısı iyi ve çok iyi olan öğrenciler, akademik başarısı orta ve altında olan öğrencilerden daha yüksek İngilizce özyeterlik inancına sahiptir. Bandura'ya (1999) göre başarılı deneyimler bireyin özyeterlik inancını güçlendirirken, başarısızlık bu inancı sarsabilir. Akademik başarı ile özyeterlik inancı arasında pozitif yönde ilişki olduğu tespit eden pek çok çalışma bu araştırma bulgusunu destekler niteliktedir (Zimmerman, 2000; Schunk ve Pajares, 2002; Multon, Brown ve Lent, 1991; Aktürk ve Aylaz, 2013, Bassi ve diğerleri, 2007; Kaya, 2016; T1lfarlıŏglu ve Çiftçi, 2011). T1lfarlığlu ve Cinkaya (2009) Yabanc1 Diller Yüksek Okulu öğrencileri üzerinde yürüttükleri araştırmada öğrencilerin İngilizce özyeterliği arttıkça dönem sonu başarıları puanlarının da arttı̆̆ sonucuna ulaşılmıştır. Öte yandan Güç (2019), çalışmasında öğrencilerin akademik performansı ile İngilizce özyeterlik inancı arasında bir ilişki bulunmadığını bildirmektedir.

Araştırmada incelenen bir diğer değişken öğrencilerin yaşadığı yer değişkenidir. Elde edilen bulgulara göre öğrencilerin İngilizce özyeterlik inancı, yaşadıkları yere göre farklılaşmaktadır. Büyükşehirde yaşayan öğrencilerin genel İngilizce özyeterlik inancı şehir, ilçe, köy vb. yerde yaşayan öğrencilerden 
daha yüksektir. Ayrıca dinleme ve okuma becerilerinde de benzer şekilde büyükşehirde yaşayan öğrenciler diğer yerleşim birimlerindekilerden daha yüksek İngilizce özyeterlik inancına sahiptir. Bu durum büyükşehirde yaşayan öğrencilerin İngilizceye ile ilgili kaynak ve etkinliklere erişebilme imkanının daha fazla olmasıyla açıklanabilir. Büyükşehirde öğrencilerin İngilizce sinema ve tiyatro gibi etkinliklere katılma şansının daha fazla olması, İngilizce kitap ve diğer kaynaklara erişiminin daha kolay olması İngilizce okuma ve dinleme özyeterlik inançlarının daha yüksek olmasını sağlamış olabilir. Literatür incelendiğinde Meera ve Jumana (2016)'nın öğrencilerin İngilizce özyeterliklerini inceledikleri çalışmasında ulaştığı sonuçlarla bu araştırma sonucunun örtüştüğü söylenebilir. Meera ve Jumana, şehirde yaşayan öğrencilerin taşrada yaşayan öğrencilerden daha yüksek İngilizce özyeterlik inancina sahip olduğunu ifade etmektedir. Ancak bunun tersine Bozkurt ve Ekşioğlu (2018) lise öğrencilerinin İngilizce özyeterliklerini incelediği çalışmasında, ilçede yaşayan öğrencilerin okuma, dinleme ve konuşma becerilerinin daha yüksek olduğunu belirtmektedir. Öte yandan yabancı dil öğretiminde dört temel becerinin de geliştirilmesinde görsel-işitsel araçların önemli bir yeri olduğu bilinmektedir (Köprülü, 2016). Nitekim Tuncer ve Akmençe (2019) öğrencilerin İngilizce dersine yönelik özyeterlik inançlarını incelediği çalışmasında, yabancı dilde TV yayını izleme sıklığı daha fazla olan öğrencilerin özyeterlik inancının daha yüksek olduğunu vurgulamaktadır.

Araştırmada incelenen diğer bir değişken öğrencilerin kaldıkları yerdir. Elde edilen bulgulara göre öğrencilerin İngilizce özyeterlik inançları, ailesi ile birlikte veya yurtta ya da bunların dışında başka bir yerde kalma durumuna göre farklılaşmamaktadır. Yani öğrenciler ister aileleriyle birlikte kendi evlerinde, ister yurtta, isterse de bir öğrenci evinde ya da akrabalarının yanında olsunlar; bu durum onların İngilizce özyeterlik inançlarını etkilememektedir. Öğrencilerin akademik başarıları ile özyeterlik inançları arasında pozitif ilişki olduğu dikkate alındığında, ailelerinin yanında kalan öğrencilerin özyeterlik inancının yüksek olması beklenebilir. Çünkü aile ortamı dışında kalan (yurt, öğrenci evi vb.) ortamlar, öğrencilerin birbirleriyle akademik iş birliği haricinde daha fazla vakit geçirdikleri, nispeten daha düzensiz bir yaşam sürdürdükleri ortam algısı uyandırabilmektedir. Geleneksel Türk aile kültüründe ise; her ne kadar araştırma kapsamındaki öğrencilerin yaşı çocuk denilebilecek kadar küçük olmasa da, Türk ebeveynlerin çocuklarına düzenli yaşam ortamı sunması ve ilgilerinin devamlılığı kuvvetle muhtemeldir. Ancak son yıllarda öğrenci yurtlarının daha konforlu bir ortam sunması ve gerek yurtlardaki gerekse öğrenci evlerindeki ortamların aile/ev ortamını aratmayacak nitelikte olması, öğrencilerin İngilizce özyeterliklerini etkilememiş olabilir.

Öğrencilerin çalışma durumu, araştırmada incelenen diğer bir kişisel değişkendir. Elde edilen bulgulara göre öğrencilerin çalışma durumu ve İngilizce özyeterlik inançları arasında anlamlı bir farklılık bulunmamaktadır. Yani öğrenciler, öğrenimleri devam ederken herhangi bir işte çalışıyor olsalar da olmasalar da benzer İngilizce özyeterlik inancına sahiptir. Başarı ve özyeterlik arasındaki ilişkiye dayanarak, öğrencilerin hem çalışıyor hem de okuyor olmalarının, onların düzenli ders çalışmaya vakit ayıramaması ihtimalini doğurabileceği düşünülmektedir. $\mathrm{Bu}$ durum, öğrencilerin başarıları ve özyeterliklerini olumsuz etkileyebileceği için her iki grup arasında da fark olabileceği beklentisi oluşturmaktadır. Bununla birlikte çalışma durumunun İngilizce özyeterliğini etkilememesi, çalışma hayatındaki başarılardan ötürü kazanılan özyeterliklerin, İngilizce özyeterliklerine nispeten yansımış olma ihtimalinden kaynaklanmış olabilir. Ya da çalışan öğrencilerin daha planlı hareket etmeye yatkın olabileceği için akademik sorumluluklarını da yerine getirmeleri ve öğrencilerin çalıştıkları iş ortamında İngilizce özyeterliğini destekleyecek görev ve sorumluluklarının bulunma ihtimali onların başarılarıyla birlikte İngilizce özyeterliklerinde nispeten etkili olabilir. Ancak bu etkinin, öğrencilerin genel olarak İngilizce özyeterliği orta düzeyde olduğu için yine de çalışan ve çalışmayan öğrenciler arasında fark oluşturacak kadar yüksek olmadığı söylenebilir.

Araştırmada incelenen son değişken aylık harcama değişkenidir. Aylık harcama değişkeni, öğrencilerin ekonomik durumlarının belirleyicisi kabul edilmiştir. Elde edilen bulgulara göre, öğrencilerin İngilizce özyeterlik inancı onların aylık harcamalarından bir diğer deyişle ekonomik durumlarından etkilenmemektedir. Her ne kadar İngilizce öğrenme; kursa gitme, özel ders alma, İngilizce kitap alma, İngilizce etkinliklere katılabilme gibi birtakım maliyetleri gerektirse de, ekonomik açıdan iyi durumda olan ya da olmayan öğrenciler bundan etkilenmemekte ve İngilizce özyeterlik inançları benzerlik göstermektedir. Bu araştırmada elde edilen bulgu, günümüzde fazla masraf etmeksizin İngilizce öğrenme imkanı sunan teknolojilere (bilgisayar, akıllı telefon, uygulamalar, internet vb.) erişimin 
kolaylaşmasından ve öğrencilerin bu teknolojilerden yaralanma imkanı bulunmasından kaynaklanıyor olabilir. Alanyazında bu bulguyu destekleyen (Bozkurt ve Ekşioğlu, 2018; Çimen, 2011) ve desteklemeyen (Kolkaya, 2019; Erdoğdu ve Yüzbaş, 2018) araştırmalara rastlamak mümkündür. Ortaöğretim öğrencilerinin İngilizce özyeterlik inançları ve kaygılarını inceleyen Kolkaya (2019), aile geliri yüksek olan öğrencilerin İngilizce özyeterlik inançlarının aile geliri düşük olanlara göre daha yüksek olduğunu tespit etmiştir. Erdoğdu ve Yüzbaş'ın (2018) yapmış olduğu çalışmada da aylık geliri yüksek olan öğrencilerin özyeterlik inançlarının daha yüksek olduğu saptanmıştır. Öte yandan Bozkurt ve Ekşioğlu'nun (2018) lise öğrencileri üzerinde yürüttüğü çalışmasında, öğrencilerin İngilizce özyeterlik inancının ailenin gelir düzeyine göre farklılık göstermediğine yönelik bulgu, bu araştırma bulgusunu destekler niteliktedir.

\section{ÖNERILER}

Araştırmanın sonuçları doğrultusunda uygulayıcılar ve araştırmacılar için şunlar önerilmektedir:

\section{Uygulayıcılara yönelik öneriler:}

1. Öğretmenler özyeterlik inancını arttırmaya yönelik olarak, cesaretlendirici geri bildirimler vermek suretiyle öğrencilerin başarı hissini tatmalarını sağlayabilirler.

2. Dilbilgisi konularının öğretmen merkezli ve sıkıcı bir şekilde verilmesi yerine onları dört temel beceri alanını da geliştirebilecek şekilde; daha çok aktif oldukları, eleştirel düşündükleri ve iletişim becerilerini geliştirebilecekleri aktivitelere daha çok yer verilebilir. Öğrencilerin ilgi duydukları konular ile ilgili araştırmalar yaparak sunumlar hazırlamaları, drama yapmaları, grupla birlikte çalışarak hikaye oluşturmaları ve anlatmaları, sınıfta İngilizce dizi/film izleyerek bunları eleştirmeleri vb. hem aktif olmalarını sağlayacak hem de temel becerileri alanlarını geliştirebilecek aktivitelere yer verilebilir. $\mathrm{Bu}$ konuda yeterli olmayan eğitimcilere rehberlik sağlanabilir.

3. Öğrencilerin İngilizce becerilerini destekleyen uyarıcılarla karşılaşması özyeterlik inancını arttırabilmektedir. Öğrencilerin ders dışında da İngilizceye vakit ayırması desteklenerek, İngilizce materyal ve kitaplar ile sinema, dizi, tiyatro ve müzik gibi etkinliklere daha kolay erişimi sağlanabilir.

4. Öğrenciler lise döneminde genellikle üniversiteye giriş sınavlarına odaklandıkları için İngilizceye duydukları ilgi ve verdikleri önem diğer derslere kıyasla azalabilmektedir. Dikkat çekici uyarıcıların bulunduğu sınıf ortamlarında öğrencilerin ilgisini çekebilecek konulara yer verilmesi derse katılımlarını arttırarak İngilizce özyeterlik inançlarını da arttırabilir.

5. Öğrencilerin özellikle İngilizce konuşmaya ilişkin özyeterlik inançlarının geliştirilmesinde hazırlık okullarında görev yapan yabancı okutmanların sayısı arttırılabilir.

6. Hazırlık okuyan öğrencilerin özyeterlik inancını etkileyen ve geliştiren etmenler göz önünde bulundurularak öğretim programları revize edilebilir.

\section{Araştırmacılara yönelik öneriler:}

1. Öğrencilerin özyeterlik inancının neden istenilen düzeyde olmadığı ve nasıl arttırılabileceğine dair derinlemesine bilgi edinebilmek için öğrenci ve öğretmenler ile görüşülerek nitel çalışmalar yapılabilir.

2. Farklı kademelerdeki öğrencilerin özyeterlik inancının üniversitedeki özeterlik inancını ne derece yordadığını belirlemeye yönelik araştırmalar yapılabilir.

\section{Bilgilendirme / Acknowledgement:}

1- Bu makale Yıldız Teknik Üniversitesi Eğitim Bilimleri Anabilim Dalı Eğitim Programları ve Öğretim bölümünde “İngilizce Hazırlık Programına Devam Eden Üniversite Öğrencilerinin İngilizce Özyeterlik İnançlarının İncelenmesi” başlıklı yüksek lisans tezinden üretilmiştir.

2-Bu çalışma 23 Şubat 2020 tarihinde gerçekleşmiş olan USVES Uluslararası Sosyal Bilimler ve Eğitim Bilimleri Sempozyumunda sözlü bildiri olarak sunulmuştur. 
3- Araştırmacıların katkı oranı eşittir.

4- Makalenin yazarları arasında çıkar çatışması bulunmamaktadır.

5- Makale verileri 2019 yılında toplanmış ve kullanılmıştır.

\section{KAYNAKÇA}

Acat, M. B. ve Demiral, S. (2002).Türkiye'de yabancı dil öğreniminde motivasyon kaynakları ve sorunları. Kuram ve Uygulamada Eğitim Yönetimi, 8(3), 312-329.

Açıkgöz - Ün, K. (2016). Etkili öğrenme ve öğretme. (9.bask1). İzmir: Biliş.

Adelodun, G. A. ve Asiru, A. B. (2015). Academic self-efficacy and gender as determinants of performance in English discourse writing among highachieving students in Ibadan, Oyo State. European Scientific Journal, 11(28), 308-318.

Akbay, S. E. ve Gizir, C. A. (2010). Cinsiyete göre üniversite öğrencilerinde akademik erteleme davranışı: Akademik güdülenme, akademik özyeterlik ve akademik yükleme stillerinin rolü. Mersin Üniversitesi Eğitim Fakültesi Dergisi, 6(1), 60-78.

Aktürk, Ü. ve Aylaz, R. (2013). Bir ilköğretim okulundaki öğrencilerin öz yeterlilik düzeyleri. Dokuz Eylül Üniversitesi Hemşirelik Fakültesi Elektronik Dergisi, 6(4), 177-183.

Arslan, A. (2018). Ortaokul öğrencilerinin yazma kaygıları ve akademik öz-yeterlik inançlarının çeşitli değişkenler açısından incelenmesi. Abant İzzet Baysal Üniversitesi Eğitim Fakültesi Dergisi, 18(3), 286-312.

Arslan, M. ve Akbarov, A. (2010). Türkiye'de yabancı dil öğretiminde motivasyon-yöntem sorunu ve çözüm önerileri. Selçuk Üniversitesi Edebiyat Fakültesi Dergisi, 24, 179-191.

Aydemir, Ö. (2007). İlköğretim II. Kademe öğrencilerinin Ingilizce dersinde kullandıkları öğrenme stratejileri ve başarı başarısızlık yüklemeleri. Yayımlanmamış yüksek lisans tezi, Trakya Üniversitesi, Edirne.

Baloğlu, E. (2011). Öğrencilerin yaşamlarında İngilizce kullanmaya yönelik öz yeterlik inançları. Yayımlanmamış yüksek lisans tezi, Orta Doğu Teknik Üniversitesi, Ankara.

Bandura, A. (1977). Social learning theory. Englewood Cliffs, N.J.: Prentice-Hall.

Bandura, A. (1982). Self efficacy mechanism in human agency. American Psychologist, 37(2), 121-147.

Bandura, A. ve Zimmerman, B. J. (1992). Self-motivation for academic attainment: the role of selfefficacy beliefs and personal goal setting. American Educational Research Journal, 29(3), 663676.

Bandura, A. (1994). Self-efficacy. Ramachaudran, V. S. (Yay. haz.) Encyclopedia of human behavior içinde (s. 71-81). New York: Academic Press.

Bandura, A. (1999). A social cognitive theory of personality. Pervin, L. ve John, O.(Yay. haz.). Handbook of personality (2. baskı) içinde (s.154-196). New York: Guilford Publications.

Bandura, A. (2000). Exercise of human agency through collective efficacy. Current Directions in Psychological Science, 9(3), 75-78.

Bassi, M., Steca, P., Fave, A. D. ve Caprara, G. V. (2007). Academic self-efficacy beliefs and quality of experience in learning. Journal of Youth Adolescence, 36, 301-312.

Bozkurt, M. A. ve Ekşioğlu, S. (2018). Lise öğrencilerinin İngilizce özyeterlik düzeyleri. KEFAD, 19(1), $40-452$.

Büyükduman, F. İ. (2006). İngilizce ögrretmen adaylarının, İngilizce ve ögretmenlik becerilerine ilişkin özyeterlik inançları arasındaki ilişki. Yayımlanmamış doktora tezi, Yıldız Teknik Üniversitesi, İstanbul. 
Can, A. (2014). SPSS ile bilimsel araştırma sürecinde nicel veri analizi (3.baskı). Ankara: Pegem Akademi.

Canbulat, M. ve İsgören, O. Ç. (2005). Yabancı dil öğretimine başlamada kullanılan en uygun yaşın ne olduğuna ilişkin dilbilimsel yaklaşımlar ve öğretmen görüșleri. Abant İzzet Baysal Üniversitesi Eğitim Fakültesi Dergisi, 5(2), 123 -139.

Coşkun, G. (2017). Üniversite öğrencilerinin İngilizce dersine ilişskin kaygıları, tutumları, özyeterlik inançları ve dil ögrenme stratejilerinin incelenmesi. Yayımlanmamış yüksek lisans tezi, Atatürk Üniversitesi, Erzurum.

Creswell, J. W. ve Clark, V. L. P. (2016). Designing and conducting mixed methods research. New York: Sage.

Çimen, S. (2011). Ë̆itim fakültesi ögrencilerinin İngilizceye yönelik tutum, İngilizce kaygısı ve öz yeterlik düzeylerinin incelenmesi. Yayımlanmamış yüksek lisans tezi, Zonguldak Karaelmas Üniversitesi, Zonguldak.

Demirpolat, B. C. 2015. Türkiye’nin yabancı dil öğretimiyle imtihanı: sorunlar ve çözüm önerileri. Ankara: SETA.

Erdoğdu, M. Y. ve Yüzbaş, D. (2018). Lise öğrencilerinin okula bağlllık ile genel öz-yeterlilik düzeyleri arasındaki ilişki. Süleyman Demirel Üniversitesi Sosyal Bilimler Enstitüsü Dergisi, 32, 205-227.

Ergür, D. (2016). Ingilizce ögrrencilerinin öz benlik saygısı ve akademik öz yeterlik algılarının bazı değişkenler açısından incelenmesi. Yayımlanmamış yüksek lisans tezi, Ağrı İbrahim Çeçen Üniversitesi, Ağrı.

Gömleksiz, M. N. (2003). İngilizce duyuşsal alana ilişkin bir tutum ölçeğinin geçerlik ve güvenirliği. Firat Üniversitesi Sosyal Bilimler Dergisi, 13, 215-226.

Gömleksiz, M. N. ve Kılınç, H. (2014). Lise 12. sınıf öğrencilerinin İngilizce öz yeterlik inançlarına ilişkin görüşleri. Firat Üniversitesi Sosyal Bilimler Dergisi, 24(2), 43-60.

Güç, F. (2019). Self-efficacy beliefs of Turkish EFL learners and the relationship between self-efficacy and academic achievement. Yayımlanmamış yüksek lisans tezi, Pamukkale Üniversitesi, Denizli.

Güler-Oğuz, F. (2019). Correlation between selfefficacy beliefs of EFL learners, their language learning strategies and attitudes towards English. Yayımlanmamış yüksek lisans tezi, Trakya Üniversitesi, Edirne.

Güneri, B. (2018). Öğrencilerin İngilizce dersi öz yeterlik inancı kaynakları, derse katıllm düzeyleri ve algılanan araçsallıklarının öz yeterlik inançları ve tutumları üzerindeki etkisi. Yayımlanmamış yüksek lisans tezi, Bülent Ecevit Üniversitesi, Zonguldak.

Hanc1- Yanar, B. ve Tümen, N. T. (2013). İngilizce ile ilgili özyeterlik inancı ölçeğinin geliştirilmesi. Kastamonu Ĕ̈itim Dergisi, 20(1), 97- 110.

Huang, C. (2013). Gender differences in academic self-efficacy: a meta-analysis. European Journal of Psychology of Education, 28, 1-35.

İşeri, K. (1996). Dilin kazanımı ve yabancı dil öğretimi. Dil Dergisi, 43, 21-27.

Jenks, C. J. (2004). The effects of age, sex and language proficiency on the self-efficacy of English language learners. ARECLS E-Journal, 1, 50-63.

Karanfil, B. (2015). Yükseköğretim İngilizce hazırlık sınıflarında güç paylaşım düzeyi ile öğrencilerin İngilizce özyeterlik algıları arasındaki ilişkinin incelenmesi. Yayımlanmamış yüksek lisans tezi, Eskişehir Osmangazi Üniversitesi, Eskişehir.

Karasar, N. (2017). Bilimsel araştırma yöntemi: Kavramlar ilkeler teknikler. (32. bask1). Ankara: Nobel Akademik Yayıncılık. 
Kaya, F. (2016). Öğrenen özerklĭgi, öz-yeterlik ve akademik başarl: Yüksekögrretimde yabancı dil ögrencilerinin bir örnek olay incelemesi. Yayımlanmamış yüksek lisans tezi, Hacettepe Üniversitesi, Ankara.

Kelch, K. ve Santana W. (2002). ESL students' attitudes toward native and nonnative-speaking instructors' accents. The CATESOL Journal, 14(1), 57-72.

Köprülü, S. G. (2016). Erken yaşta yabancı dil öğreniminde çizgi filmlerin yeri. Diyalog Interkulturelle Zeitschrift Für Germanistik, 4(1) 88-98.

Meera, K.P. ve Jumana, M. K. (2016). Self-efficacy and academic performance in English. Imperial Journal of Interdisciplinary Research, 2(2), 79-83.

Morgan, D. L. ve Morgan, R. K. (2008). Single-case research methods for the behavioral and health sciences. Thousand Oaks CA: SAGE Publications.

Multon, K. D., Brown, S. D. ve Lent, R. W. (1991). Relation of self-efficacy beliefs to academic outcomes: a meta-analytic investigation. Journal of Counseling Psychology, 38(1), 30-38.

Necan, Y. (2019). Lise 11. sınıf öğrencilerinin İngilizceye yönelik özyeterlik inanç düzeylerinin incelenmesi. Yayımlamamış yüksek lisans tezi, Bolu Abant İzzet Baysal Üniversitesi, Bolu.

Netz, Y. ve Raviv, S. (2004). Age differences in motivational orientation toward physical activity: An application of social cognitive theory. The Journal of Psychology, 138(1), 35-48.

Senemoğlu, N. (2018). Gelişim, ögrenme ve öğretim. (26.baskı). Ankara: Anı Yayıncılık.

Şubaş, R. (2018). Okul öncesi ögretmen adaylarının öz-denetimleri ve ögretmen özyeterlik inançları arasındaki ilişkinin bazı değişkenlerle incelenmesi. Yayımlanmamış yüksek lisans tezi, Dumlupınar Üniversitesi, Kütahya.

Oğuz, A. ve Akkaş- Baysal, E. (2015). Ortaöğretim öğrencilerinin İngilizce öğrenme kaygıları ile İngilizce özyeterlik inançlarının incelenmesi Eğitim ve Öğretim Araştırmaları Dergisi, 4(3), 107-117.

Pajares, F. (2002). Gender and perceived self-efficacy in self-regulated learning. Theory Into Practice. 41(2), 116-125.

Pamuk, İ. (2014). The relationship among self-efficacy, attitude and performance in English writing classes at tertıary level. Yayımlanmamış yüksek lisans tezi, Ufuk Üniversitesi, Ankara.

Raoofi, S., Tan, B. H. ve Chan, S. H. (2011). Self-efficacy in second/foreign language learning contexts. English Language Teaching, 5(11), 60-73.

Sani, A. M. ve Zain, Z. (2011). Relating adolescents' second language reading attitudes, self efficacy for reading, and reading ability in a non-supportive ESL setting. The Reading Matrix, 11(3), 243253.

Schunk, D. ve Pajares, F. (2001). The development of academic self-efficacy. Development of Achievement Motivation, 30, 15- 31.

Schunk, D. H. ve Pajares, F. (2002). The development of academic self-efficacy. Wigfield A. ve Jacquelyne S. E. (Yay. haz.). Development of Achievement Motivation içinde (s.16-29). USA: Academic Press.

Sevimbay, A. (2016). 11.sınıf ögrencilerinin İngilizce dersine yönelik tutumları ve özyeterlik inançları arasındaki ilişskiler. Yayımlanmamış yüksek lisans tezi, Bartın Üniversitesi, Bartın.

Siritararatn, N. (2013). English self-efficacy beliefs of EFL low proficiency graduate students. Academic Journal of Interdisciplinary Studies, 2(3), 461- 468.

Şener, S. ve Erol, İ. K. (2017). Motivational orientations and self efficacy beliefs of Turkish students towards EFL learning. Eurasian Journal of Educational Research, 67, 251-267. 
Taşdemir, H. (2018). Exploring the relationship between high school students' willingness to communicate and their selfefficacy perceptions in Turkish EFL context. Yayımlanmamış yüksek lisans tezi, Çağ Üniversitesi, Mersin.

British Council- TEPAV Proje Ekibi. (2013). Türkiye'deki devlet okullarında ingilizce dilinin öğretimine ilişkin ulusal ihtiyaç analiz. Ankara: British Council.

T1lfarlığlu, F. Y. ve Cinkara, E. (2009). Self-efficacy in EFL: Differences among proficiency groups and relationship with success. Novitas-ROYAL, 3(2), 129- 142.

T1lfarlığlu, F. T. ve Çiftçi, F. Ş. (2011). "Supporting self-efficacy and learner autonomy in relation to academic success in EFL classrooms (A case study). Theory and Practice in Language Studies, l(10), 284-294.

Tuncer, M. ve Akmençe, A. E. (2019). Lise öğrencilerinin İngilizce dili özyeterlik inançlarının araştırılması. Electronic Journal of Education Sciences, 8(16), 97-111.

Turanlı, A. S. (2007). Sosyal bilişsel öğrenme ve yabanc1 dil öğretimi. Sosyal Bilimler Enstitüsü Dergisi, $23,1-15$.

Uçar, H. (2012). İngilizce ögretmen adaylarının özyeterlik inancı, başarı yönelimi ve çevrimiçi öğrenme ortamına katılım durumu: Uzaktan IÖLP örneği. Yayımlanmamış yüksek lisans tezi, Anadolu Üniversitesi, Eskişehir.

Uygur, M. (2010). Ingiliz dili eğitimi anabilim dalı lisans öğrencilerinin öz-yeterlik algılarının farklı değişkenlere göre incelenmesi. Yayımlanmamış yüksek lisans tezi, Mersin Üniversitesi, Mersin.

Ülkümen, H. A. (2013). İngilizce hazırlık okulu okutmanlarının özyeterlik inançlarının yordayıcıları. Yayımlanmamış yüksek lisans tezi, Orta Doğu Teknik Üniversitesi, Ankara.

White, A. R. ve Bowers, D. C. (2008). The relationship among race, gender, and high school students' self-efficacy in English language arts. Yayımlanmamış doktora tezi, Fordham University, New $\begin{array}{lllll}\text { York. } & 1 & \text { Haziran } & 2019 & \text { tarihinde }\end{array}$ https://search.proquest.com/docview/304639474? accountid=131581 adresinden erişildi.

Woolfolk, A. (2016). Educational Psychology (13.baskı). England: PEARSON Education Limited.

Zimmerman, B. J. (2000). Self-efficacy: An essential motive to learn. Contemporary Educational Psychology, 25(1), 82-91. 